\title{
Behavioral, Neurophysiological, and Synaptic Impairment in a Transgenic Neuregulin1 (NRG1-IV) Murine Schizophrenia Model
}

\author{
Francesco Papaleo, ${ }^{1,2}$ - Feng Yang, ${ }^{1,3 *}$ Clare Paterson, ${ }^{4 \star}$ (DSara Palumbo, ${ }^{1,5}$ Gregory V. Carr, ${ }^{1,5}$ Yanhong Wang, ${ }^{1,3}$ \\ Kirsten Floyd, ${ }^{4}$ Wenwei Huang, ${ }^{6}$ Craig J. Thomas, ${ }^{6}$ Jingshan Chen, ${ }^{1}$ Daniel R. Weinberger, ${ }^{1,3,7}$ and Amanda J. Law ${ }^{1,4,8}$ \\ ${ }^{1}$ Clinical Brain Disorders Branch, Genes, Cognition and Psychosis Program, National Institute of Mental Health, National Institutes of Health, Department \\ of Health and Human Services, Bethesda, Maryland 20892, ${ }^{2}$ Department of Neuroscience and Brain Technologies, Istituto Italiano di Tecnologia, via \\ Morego, 30, Genova 16163, Italy, ${ }^{3}$ Lieber Institute for Brain Development, Johns Hopkins University Medical Campus, Baltimore, Maryland 21205, \\ ${ }^{4}$ University of Colorado, School of Medicine, Department of Psychiatry, Aurora, Colorado 80045, ${ }^{5}$ Laboratory of Molecular Biology, Department of Surgical, \\ Medical and Molecular Pathology and of Critical Care, University of Pisa, Pisa I-56126, Italy, ${ }^{6}$ National Center for Advancing Translational Sciences, \\ National Institutes of Health, Rockville, Maryland 20850, ${ }^{7}$ Departments of Psychiatry, Neurology, and Neuroscience, and the McKusick-Nathans Institute of \\ Genetic Medicine, Johns Hopkins School of Medicine, Baltimore, Maryland 21205, and ${ }^{8}$ University of Colorado, School of Medicine, Department of Cell and \\ Developmental Biology, Aurora, Colorado 80045
}

Schizophrenia is a chronic, disabling neuropsychiatric disorder with complex genetic origins. The development of strategies for genome manipulation in rodents provides a platform for understanding the pathogenic role of genes and for testing novel therapeutic agents. Neuregulin 1 (NRG1), a critical developmental neurotrophin, is associated with schizophrenia. The NRG1 gene undergoes extensive alternative splicing and, to date, little is known about the neurobiology of a novel NRG1 isoform, NRG1-IV, which is increased in the brains of individuals with schizophrenia and associated with genetic risk variation. Here, we developed a transgenic mouse model (NRG1-IV/NSE-tTA) in which human NRG1-IV is selectively overexpressed in a neuronal specific manner. Using a combination of molecular, biochemical, electrophysiological, and behavioral analyses, we demonstrate that NRG1-IV/NSE-tTA mice exhibit abnormal behaviors relevant to schizophrenia, including impaired sensorimotor gating, discrimination memory, and social behaviors. These neurobehavioral phenotypes are accompanied by increases in cortical expression of the NRG1 receptor, ErbB4 and the downstream signaling target, PIK3-p110 $\delta$, along with disrupted dendritic development, synaptic pathology, and altered prefrontal cortical excitatory-inhibitory balance. Pharmacological inhibition of p $110 \delta$ reversed sensorimotor gating and cognitive deficits. These data demonstrate a novel role for NRG1-IV in learning, memory, and neural circuit formation and a potential neurobiological mechanism for schizophrenia risk; show that deficits are pharmacologically reversible in adulthood; and further highlight p110 $\delta$ as a target for antipsychotic drug development.

Key words: AKT; ErbB; IC87114; neuregulin; PIK3CD; schizophrenia

Significance Statement

Schizophrenia is a disabling psychiatric disorder with neurodevelopmental origins. Genes that increase risk for schizophrenia have been identified. Understanding how these genes affect brain development and function is necessary. This work is the first report of a newly generated humanized transgenic mouse model engineered to express human NRG1-IV, an isoform of the NRG1 (Neuregulin 1) gene that is increased in the brains of patients with schizophrenia in association with genetic risk. Using behavioral neuroscience, molecular biology, electrophysiology, and pharmacology, we identify a role for NRG1-IV in learning, memory, and cognition and determine that this relates to brain excitatory-inhibitory balance and changes in ErbB4/PI3K/AKT signaling. Moreover, the study further highlights the potential of targeting the PI3K pathway for the treatment of schizophrenia.

\section{Introduction}

Schizophrenia is a multifactorial brain disorder with complex genetic, neurodevelopmental, and environmental origins (Wein-

Received Dec. 24, 2015; revised March 3, 2016; accepted March 22, 2016

Author contributions: F.P., F.Y., C.P., S.P., G.V.C., J.C., D.R.W., and A.J.L. designed research; F.P., F.Y., C.P., S.P., G.V.C., Y.W., K.F., J.C., and A.J.L. performed research; K.F., W.H., C.J.T., J.C., and D.R.W. contributed unpublished berger, 1987; Rapoport et al., 2012; Howes and Murray, 2014; Schizophrenia Working Group of the Psychiatric Genomics

reagents/analytic tools; F.P., F.Y., C.P., S.P., G.V.C., Y.W., J.C., and A.J.L. analyzed data; F.P., J.C., D.R.W., and A.J.L. wrote the paper.

This work was supported by funding from the National Institute of Mental Health (NIMH) Intramural Research Program, National Institutes of Health (NIH) to A.J.L and D.R.W., and by extramural funding from the NIH, 
Consortium, 2014). It is characterized by severe disturbances in perception and cognition (Weickert et al., 2000; Schaefer et al., 2013; Young and Geyer, 2015) and deficits attributed to abnormal development of prefrontal cortical (PFC) and hippocampal neuronal circuitry represent cardinal features of the illness that cannot be treated by existing antipsychotic medications (Callicott et al., 2003; Toulopoulou et al., 2010; Rasetti et al., 2011; Schaefer et al., 2013). Neuregulin 1 (NRG1) and its receptor, ErbB4, are candidate susceptibility genes for schizophrenia (B1ouin et al., 1998; Badner and Gershon, 2002; Stefansson et al., 2002; Stefansson et al., 2003; Corvin et al., 2004; Silberberg et al., 2006; Li et al., 2007; Law et al., 2012; Agim et al., 2013) and recent genome-wide association studies identify polymorphisms in these genes that contribute to neuronal molecular pathways underlying psychiatric genetic risk (Network and Pathway Analysis Subgroup of Psychiatric Genomics, 2015). Furthermore, polymorphisms in NRG1 and ErbB4 have been linked to human brain development, cognitive dysfunction, and psychotic symptomatology (Hahn et al., 2006; Hall et al., 2006; Nicodemus et al., 2006; Knickmeyer et al., 2014).

NRG1 is a potent regulator of neuronal development and synaptic function (Harrison and Law, 2006; Mei and Nave, 2014) and has recently been implicated in cortical GABAergic and glutamatergic circuit development (Fazzari et al., 2010; Wen et al., 2010; Mei and Nave, 2014). The human NRG1 gene (8p21-p12) encodes multiple alternative transcripts that are classified as types I-VI, differing in their tissue expression and function (Harrison and Law, 2006; Mei and Nave, 2014). The majority of schizophrenia-associated polymorphisms are noncoding (Stefansson et al., 2002; Stefansson et al., 2003; Corvin et al., 2004; Li et al., 2007; Agim et al., 2013). The observation that a well studied NRG1 risk haplotype ( Hap $\left._{\text {ice }}\right)$ resides in the $5^{\prime}$ promoter (Stefansson et al., 2002; Stefansson et al., 2003) suggests that dysregulation of NRG1 gene expression represents a molecular mechanism of risk. Indeed, the Hap ice $_{\text {haplotype which is }}$ associated with a 2-fold increase in risk (Stefansson et al., 2002), has been associated with differential expression of NRG1 in schizophrenia brain (Law et al., 2006; Nicodemus et al., 2009; Moon et al., 2011; Weickert et al., 2012).

Our previous work in postmortem human brain (Law et al., 2006) identified an association of rs6994992, a functional polymorphism (Tan et al., 2007) and marker of the Hap ice risk haplotype, with transcriptional expression of NRG1-IV (Law et al., 2006; Moon et al., 2011), a brain-specific developmentally regulated isoform. Individuals carrying the risk allele exhibit elevated levels of NRG1-IV in PFC and hippocampus (Law et al., 2006; Moon et al., 2011). Neuroimaging, neurocognitive, and postmortem studies in humans have subsequently demonstrated rs6994992's association with sensorimotor gating, cognitive function, and adult brain structure (Hall et al., 2006; Stefanis et al., 2007; Kéri et al., 2009; Greenwood et al., 2011), as well as neocortical structure in the human neonate

NIMH to A.J.L (P50 MH-086383-06 and R01 MH103716-02). Support was also provided by the Sidney R. Baer, Jr. Award. Outstanding Research Achievement Prize for Schizophrenia Research from the Brain and Behavior Research Foundation/NARSAD and the Dr. Nancy Gary Endowed Chair in Children's Mental Health Disorders, both held by A.J.L. We thank Dr. James Pickel and the NIMH Division of Intramural Programs, Transgenic Core Facility for mouse oocyte injections, Mr. Qingjun Tian of NIMH, NIH for genotyping and mouse brain dissections and Dr. Wei Tan of NCI, $\mathrm{NIH}$ for original EF372273 construct synthesis.

The authors declare no competing financial interests.

*F.Y. and C.P. contributed equally to this work.

Correspondence should be addressed to Amanda J. Law, Departments of Psychiatry and Cell and Developmental Biology, University of Colorado, School of Medicine, 12700 East 19th Avenue, Mailstop 8619, RC2, Rm. 4100C, Aurora, Colorado 80045. E-mail: amanda.law@ucdenver.edu.

DOI:10.1523/JNEUROSCI.4632-15.2016

Copyright $\odot 2016$ the authors $\quad 0270-6474 / 16 / 364860-17 \$ 15.00 / 0$
(Knickmeyer et al., 2014) and NRG1-IV splicing in the fetal brain (Paterson et al., 2014). These results suggest an unexplored role for NRG1-IV in human neural circuit development and function.

Although previous studies have investigated the role of NRG1 signaling in rodent neural development and behaviors relevant to schizophrenia (Stefansson et al., 2002; Fazzari et al., 2010; Deakin et al., 2012; Yin et al., 2013; Agarwal et al., 2014; Law, 2014; Luo et al., 2014; Paterson and Law, 2014), the role of NRG1-IV remains unknown. Here, we developed a transgenic mouse model of human NRG1-IV dysregulation associated with a molecular pathology of NRG1 in schizophrenia and investigated the neurobiological consequences. Furthermore, we investigated a signaling link between increased NRG1-IV and changes in the ErbB4, PI3K-AKT pathway, as seen in schizophrenia (Silberberg et al., 2006; Law et al., 2007; Law et al., 2012), and whether abnormal behaviors could be reversed via pharmacological inhibition of this pathway (Law et al., 2012). We found that mice genetically engineered to express human NRG1-IV in a neuron-specific manner exhibit behavioral abnormalities, including deficits in sensorimotor gating, and cognitive and social function. NRG1-IV altered the balance of cortical excitatory-inhibitory (E/I) neurotransmission and decreased neuronal spine density and dendritic development ex vivo. Cortical ErbB4 and PIK3CD protein

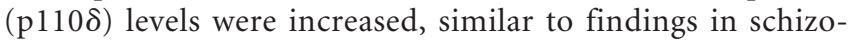
phrenia (Silberberg et al., 2006; Law et al., 2007; Law et al., 2012), and p110 $\delta$ inhibition using IC87714 ameliorated behavioral deficits, including cognitive deficits dependent on medial PFC (mPFC) and hippocampal function.

\section{Materials and Methods}

\section{Transgenic mouse engineering}

Human NRG1-IV cDNA (GenBank accession no. EF372273; Tan et al., 2007) was amplified by PCR and cloned into the pCR2.1-TOPO vector (Invitrogen). The NRG1-IV coding sequence was subcloned into the Sal1 site of the tetracycline-regulated pTet-splice vector under the control of a tetracycline-responsive promoter. The new plasmid was designated as pTet-NRG1-IV. The sequences and the orientation of NRG1-IV were confirmed by conventional Sanger sequencing. A DNA fragment containing the tetracycline-responsive promoter, the human NRG1-IV coding sequence, a small SV40 intron, and a SV40 poly(A) signal was released from the pTet-NRG1-IV by digestion with XhoI and NotI and isolated from gel with a QIAGEN Gel Extraction kit. DNA was filtered with a 0.22 $\mu \mathrm{m}$ Millipore filter and diluted with $1 \mathrm{~mm}$ Tris- $\mathrm{HCl}, \mathrm{pH}$ 7.5, $0.05 \mathrm{~mm}$ EDTA buffer to $10 \mu \mathrm{g} / \mathrm{ml}$. DNA was microinjected into the pronuclei of 200 fertilized embryos from the mating of C57BL/6J mice. Microinjected embryos were implanted into $10-15$ pseudopregnant recipients using the National Institute of Mental Health (NIMH)-National Institutes of Health (NIH) transgenic core facility. The founder mice were identified by PCR genotyping with specific primers and confirmed in separate experiments. C57BL/6 NRG1-IV transgenic mice were crossbred with C57BL/6 neuron-specific enolase (NSE)-tetracycline transactivator (tTA) transgenic mice (donated by Eric J Nestler, now available at The Jackson Laboratory; B6.Cg-Tg(Eno2tTA)5030Nes/J. A line, also see Chen et al., 1998) to achieve bigenic offspring with neuron-specific expression of NRG1-IV (NRG1-IV/NSE-tTA; Fig. 1A,B). Genotyping of transgenic mice was performed by PCR analysis of DNA extracted from tail clips taken at $21 \mathrm{~d}$ of age. In brief, DNA was used as a template for PCR amplification of NRG1-IV and NSE using the following primers: NRG1-IV forward ( $5^{\prime}$-GGC AGC AGC ATG GGG AAA GGA-3'), NRG1-IV reverse (5'-GCT TGT AGA AGC TGG CCA TTA CGT-3'), NSE forward ( $5^{\prime}$-CTA CCA GCT ATG TCT GTA GAG ACA-3') and NSE reverse ( $5^{\prime}$-GTC CTC ATC CAT CAC TGC TTC CA- ${ }^{\prime}$; Fig. $1 B$ ). We confirmed mRNA expression of human NRG1-IV in the brains of bigenic transgenic mice and absence of expression in wild-type (WT) 

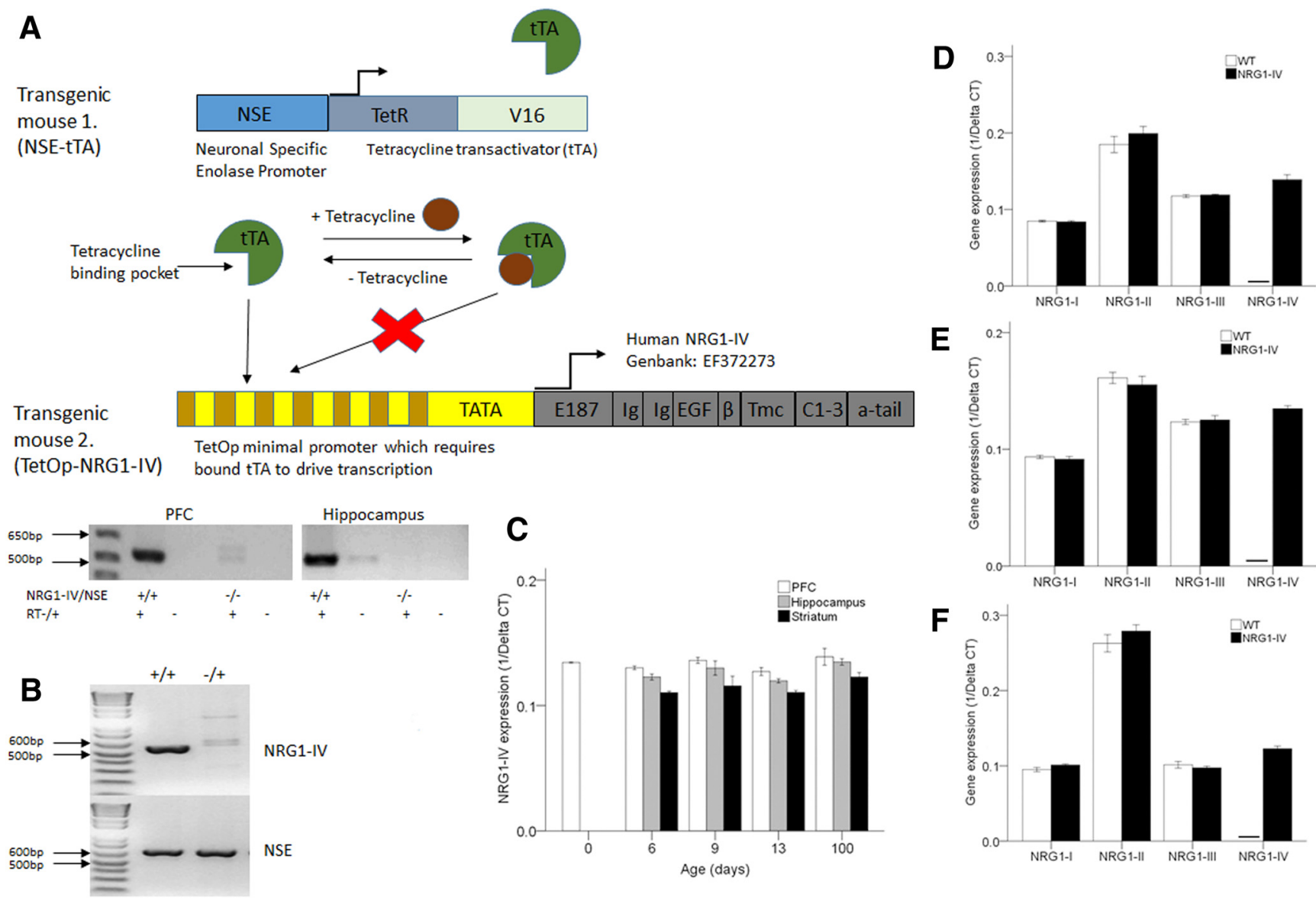

Figure 1. Transgenic construct design and tissue-specific expression profiling of the NRG1-IV transgene and endogenous NRG1 splice isoforms types I-III in mouse brain across development. $A$, Schematic of the TET-OFF transgenic technology used in the generation of NRG1-IV/NSE-TTA mice. Transgenic mice 1, which encode tTA under the control of the NSE promoter, are cross-bred with transgenic mice 2, which encode human NRG1-IV under the control of the tetracycline-responsive promoter TetOP. In bigenic mice $(+/+)$, tTA drives NRG1-IV expression to create NRG1-IV/NSE-tTA transgenics. For original and complete structure of NRG1-IV-EF372273, see (Tan et al., 2007). Bottom, RT-PCR expression of human NRG1-IV in hippocampus and PFC of NRG1-IV/NSE-tTA mice (+/+). B, Bigenic genotyping for human NRG1-IV and NSE. + / + denotes NRG1-IV/NSE-TTA mice that express the transgene; - / + denotes NSE control littermates who do not express NRG1-IV. C, Quantitative RT-PCR expression analysis of NRG1-IV transgene expression in the mPFC, hippocampus, and striatum of NRG1-IV/NSE-tTA mice. C, Day 0, $n=5$ (PFC only; hippocampus and striatum not available for dissection); day $6, n=7$; day 9, $n=5 ;$ day 13 , $n=8 ;$ day $100, n=8$. D- $\boldsymbol{F}$, NRG1-IV, $n=8 ; \mathrm{WT}, n=6$ at PND 100. $\boldsymbol{D}$ is the PFC; $\boldsymbol{E}$, hippocampus; $\boldsymbol{F}$, striatum. Horizontal bar denotes absence of detectable expression.

littermates using RT-PCR and quantitative RT-PCR (Fig. 1, $A$ and $C$ ). WT mice refers to littermates who carried neither the NRG1-IV or NSE $(-/-)$ or the NSE $(-/+)$ gene alone. Absence of human NRG1-IV expression was observed in both WT genotypes and no impact of the NSE genotype alone was observed on any measure.

All animal procedures were in accordance with and approved by the NIMH Animal Care and Use Committee and followed the NIH's Using Animals in Intramural Research and the University of Colorado Denver Institutional Animal Care and Use Committee. All NRG1-IV/NSE-tTA and control mice used were littermates. Mice were group housed (2-4 animals per cage $)$ in a climate-controlled animal facility $\left(22 \pm 2{ }^{\circ} \mathrm{C}\right)$, maintained on a $12 \mathrm{~h} \mathrm{light/dark} \mathrm{cycle,} \mathrm{and} \mathrm{fed} \mathrm{ad} \mathrm{libitum.} \mathrm{Behavioral}$ testing was conducted in 3- to 7-month old male mice during the light phase. Experimenters were blinded to genotype during all behavioral testing and data analysis. Mice were handled by the same experimenter on alternate days during the week preceding the tests. Sample size for each experiment was determined on the basis of preliminary data derived for each test.

\section{Physical health}

Measures of general health and neurological reflexes were assessed in the mice as described previously (Moy et al., 2004; Papaleo et al., 2008). General health measures included posture, physical condition of the fur, observations for unusual home cage behaviors, empty cage observations for $3 \mathrm{~min}$, and irregular spontaneous behaviors such as excessive grooming, digging, rearing, or stereotypy. Neurological reflexes exam- ined included trunk curl, forepaw reaching, corneal reflex, ear twitch, whisker twitch, and the righting reflex. The wire hang test to evaluate limb strength was performed by placing the mouse on one set of wire bars and then inverting the lid for a cutoff time of $60 \mathrm{~s}$.

\section{Comprehensive behavioral assessment}

Startle and prepulse inhibition test. Startle responses and prepulse inhibition (PPI) were measured using four SR-Lab Systems (San Diego Instruments) as described previously in detail (Papaleo et al., 2008; Paterson and Law, 2014). Briefly, mice were placed into the SR-Lab Systems. A 5 min acclimation period was followed by $10.5 \mathrm{~min}$ of 7 randomized trial types across 6 discrete blocks for a total of 42 trials. The interval between trials was $10-20 \mathrm{~s}$. One trial measured the response to no stimulus (baseline movement) and another the response to the startle stimulus alone (acoustic amplitude), which was a $40 \mathrm{~ms}, 120 \mathrm{~dB}$ sound burst. The other five trials were acoustic prepulse + acoustic startle stimulus trials. Prepulse tones were $20 \mathrm{~ms}$ at $74,78,82,86$, and $90 \mathrm{~dB}$, which were presented $100 \mathrm{~ms}$ before the startle stimulus. The background level was maintained at $70 \mathrm{~dB}$. To determine percentage inhibition (\% PPI), the average response at a decibel was divided by the response of acoustic startle, multiplied by 100, and subtracted from 100 .

Locomotor activity, temporal order, object location and novel object discrimination tasks. Mice were tested in an experimental apparatus consisting of four Plexiglas Digiscan automated open fields (Accuscan; $42 \times$ $42 \times 30 \mathrm{~cm}$ ). One red light was placed overhead the apparatus, evenly illuminating each open field ( $5 \pm 2 \mathrm{lux}$ ). Each apparatus contained pho- 
tobeam sensors to quantify exploratory and locomotor behaviors. The temporal order object recognition test, in which discriminations are based on the relative recency of presented objects, was as described previously (Barker et al., 2007; Barker and Warburton, 2011). Briefly, this test measure a rodent's ability to differentiate between two familiar objects presented at different intervals. The temporal order test was run in 3 5 min sessions. For all three sessions, mice were placed in the Plexiglas apparatus that they were placed in during the habituation period from the day before. A $1 \mathrm{~h}$ time period spanned between the first and second session and a $3 \mathrm{~h}$ time period between the second and third sessions. During the first session, mice were placed in the apparatus with two identical objects and allowed to explore. During the second session, mice were placed with two different identical objects and allowed to explore. During the third session ("test phase"), mice were placed with duplicates of each object from the previous two sessions and allowed to explore. If temporal order memory is intact, the subjects will spend more time exploring the object from session 1 (i.e., the object presented less recently) compared with the object from session 2 (i.e., the more recent object). Discrimination between the objects was calculated using a discrimination ratio that takes into account individual differences in the total amount of exploration. In particular, the discrimination ratio was calculated as the difference in time spent exploring the object from sample phase 1 compared with the object from sample phase 2 divided by the total time spent exploring both objects during the test period. If temporal order discrimination memory is intact, subjects exhibit a discrimination ratio $>0$. For the temporal order discrimination, object location and novel object recognition tasks the same apparatus and objects were used. The objects consisted of 2 rectangular boxes $(3 \times 3 \times 6 \mathrm{~cm})$ or 2 laboratory flasks $(4 \times 6 \mathrm{~cm})$ that were either black or white. The positions of the objects in the test and the objects used in the different phases were counterbalanced between the genotypes. Each session was video recorded using a Sony Handycam with the experimenter absent from the room during the test. Time spent exploring each object was subsequently scored from the videotapes as the number of seconds when each subject was facing the object and $\leq 1 \mathrm{~cm}$ away. Any subjects that failed to complete a minimum of $2 \mathrm{~s}$ of exploration in the experimental phases were excluded from the analysis.

Object location test. The object location test was used as described previously with small changes (Barker et al., 2007; Papaleo et al., 2008). A separate group of naive mice was used. The day after the $1 \mathrm{~h}$ habituation in the empty open-field arena, each mouse was introduced for $10 \mathrm{~min}$ into the open field, which contained two identical copies of the same object. The $5 \mathrm{~min}$ test phase took place $1 \mathrm{~h}$ after the acquisition trial. In the test phase, the mice were placed back into the same arena with the same objects as that in the acquisition phase, which therefore were of equal novelty, but one object had been "misplaced" to a new location (the adjacent corner of its original position). The position of the misplaced object was counterbalanced between mice. An exploratory preference index, the ratio of the amount of time spent exploring the misplaced object over the total time spent exploring both objects, was used to measure the object location memory. If object location memory is intact, subjects exhibit a discrimination ratio $>0.5$

Novel object recognition test. The novel object recognition test was used as described previously with small changes (Barker et al., 2007; Papaleo et al., 2008). A separate group of naive mice was used. The day after the $1 \mathrm{~h}$ habituation in the empty open-field arena, each mouse was introduced for $10 \mathrm{~min}$ into the open field, which contained 2 identical copies of the same object. The 5 min test phase took place $2 \mathrm{~h}$ after the acquisition trial. The mice were placed back into the same arena with a duplicate of the old object and the new object of the opposite color and shape. The discrimination ratio for recognition memory was calculated as the difference in time spent exploring the novel object minus the familiar object divided by the total time spent exploring both objects during the test period. If novel object memory is intact, subjects exhibit a discrimination ratio $>0$.

Fear conditioning. A conditioning chamber (San Diego Instruments Freeze Monitor System) was used as described previously (Papaleo et al., 2011). The floor grid was wired to a shock generator and scrambler. Background noise level was $65 \mathrm{~dB}$ and overhead lighting was used (Lux 500). To provide a novel environment, a white-walled triangular chamber with a Plexiglas bottom was used to test the tone cue. A $1 \%$ vanilla extract solution was used for a novel scent. Instead of overhead lighting, a dim lamp (80 lux) was used. The conditioned stimulus (CS) was an $80 \mathrm{~dB}$ tone lasting $30 \mathrm{~s}$. The unconditioned stimulus (US) was a $2 \mathrm{~s}$ scrambled foot shock delivered to the floor grid with an intensity of 0.5 $\mathrm{mA}$ (tone and shock coterminating). The experiment took place over $2 \mathrm{~d}$. On day 1, each mouse was monitored for freezing (absence of all movements except those related to respiration) during a 2 min baseline in the conditioning chamber. Freezing was monitored using a digital stopwatch to determine time spent freezing. Then, three $30 \mathrm{~s}$ conditioning trials with 90 s intertrial delays (CS coterminating with US) followed. After the conditioning trials, subjects were monitored for $2 \mathrm{~min}$ after conditioning (i.e., after training). On day 2, subjects were returned to the original context and monitored for a 5 min period (context). Two hours after context testing, subjects were retested in a novel environment. Baseline freezing was monitored for $2 \mathrm{~min}$. After the $2 \mathrm{~min}$ period, subjects were exposed to the CS and monitored. After the CS, subjects were monitored for an additional $2 \mathrm{~min}$.

Social approach test. Social approach was tested in an automated threechambered apparatus using methods described previously for sociability and preference for social novelty (Moy et al., 2004; Paterson and Law, 2014). Number of entries and time spent in the chambers were automatically recorded from photocells embedded in the doorways. Mice used as the novel stimulus target were $\mathrm{C} 57 \mathrm{BL} / 6 \mathrm{~J}$ that were matched to the subject mice by sex and age.

\section{Electrophysiology}

Male WT and NRG1-IV/NSE-tTA mice, postnatal weeks 8-10, were euthanized after being anesthetized with isoflurane. The brains were quickly removed and 300- $\mu \mathrm{m}$-thick coronal slices containing frontal cortex were cut on a compresstome (VF-200, Presionary; Ji et al., 2009). Slices were maintained in oxygenated ice-cold $\mathrm{Na}^{+}$-free sucrose solution containing the following (in mM): $2.5 \mathrm{KCl}, 1.25 \mathrm{NaH}_{2} \mathrm{PO}_{4}, 26 \mathrm{NaHCO}_{3}$, $0.5 \mathrm{CaCl}_{2}, 4.0 \mathrm{MgCl}_{2}$, and 250 sucrose. Slices were initially incubated at $34^{\circ} \mathrm{C}$ in Ringer's solution (artificial CSF, or ACSF) containing the following (in mM): $125 \mathrm{NaCl}, 2.5 \mathrm{KCl}, 1.25 \mathrm{NaH}_{2} \mathrm{PO}_{4}, 2 \mathrm{CaCl}_{2}, 1 \mathrm{MgCl}_{2}, 26$ $\mathrm{NaHCO}_{3}$, and 10 dextrose, $\mathrm{pH} 7.4$, and then maintained at room temperature. Slices were equilibrated for at least $30 \mathrm{~min}$ before recording. Recordings were made at $32-34^{\circ} \mathrm{C}$. For current clamp, the recording pipettes were filled with intracellular solution containing the following (in mM): $130 \mathrm{~K}$-gluconate, $1 \mathrm{MgCl}_{2}, 5$ EGTA, $5 \mathrm{MgATP}, 10 \mathrm{HEPES}$, and $0.4 \mathrm{Na}_{2} \mathrm{GTP}$, pH 7.2 with $\mathrm{KOH}$. Patch pipette resistance was $4-7 \mathrm{M} \Omega$. Whole-cell recordings were obtained with Axopatch 200B amplifiers (Molecular Devices), filtered at $2 \mathrm{kHz}$, and sampling was acquired at intervals of 20-100 $\mu$ s through a DigiData 1321A interface with program pCLAMP 10 (Molecular Devices), as described previously (Ji et al., 2009). Miniature EPSCs (mEPSCs) were recorded with a holding potential at $-70 \mathrm{mV}$ in the presence of $10 \mu \mathrm{M}$ bicuculline and $2 \mu \mathrm{M}$ tetrodotoxin (Sigma-Aldrich) to block $\mathrm{GABA}_{\mathrm{A}}$ receptor currents and voltage-gated sodium currents, respectively. To record miniature IPSCs (mIPSCs), a different $\mathrm{Cs}^{+}$-based intracellular solution containing the following (in mm): $134 \mathrm{CsCl}_{2}, 2 \mathrm{MgCl}_{2}, 2 \mathrm{Na}_{2}$-ATP, $0.5 \quad \mathrm{Na}_{2} \mathrm{GTP}, 5 \quad \mathrm{Na}_{2}-$ phosphocreatine, 1 EGTA, and 10 HEPES, along with $0.3 \%$ biocytin, $\mathrm{pH}$ 7.25 , was used. The mIPSCs were recorded at $-70 \mathrm{mV}$ in the presence of $50 \mu \mathrm{M}$ CNQX (Sigma-Aldrich), $50 \mu \mathrm{M}$ D-APV (Sigma-Aldrich), and $2 \mu \mathrm{M}$ tetrodotoxin. The access resistance was monitored during recordings and data were excluded from analysis if the series resistance changed $>20 \%$ from control levels (10-25 M $\Omega$ ). Spontaneous EPSCs (sEPSCs) and IPSCs (sIPSCs) were recorded in voltage-clamp mode and analyzed with Clampfit 10 (Molecular Devices). A typical EPSC and a typical IPSC were selected to create a sample template for event detection within a data period (Ji et al., 2009). The frequency (event number) and amplitude of individual events were calculated with Clampfit. The input resistances of the tested neurons were calculated offline from the voltage produced by negative current injection $(-20 \mathrm{pA})$ before the step currents.

The prefrontal layer $\mathrm{V}$ interneurons were identified based on their morphological characteristics and electrophysiological properties as described previously (Kawaguchi, 1995; Xiang et al., 1998; Ji et al., 2009). Using the criteria described below, we were able to unambiguously clas- 
sify the recorded layer $\mathrm{V}$ interneurons into three categories: fast spiking (FS), regular spiking (RS), and low-threshold spiking (LTS). An FS cell was identified by its high-frequency firing of action potentials without adaptation, short half-width, large fast afterhyperpolarization (fAHP), and spontaneous postsynaptic potentials with high frequency and large amplitude. An RS interneuron has adaptive firing, wider action potentials, relatively less spontaneous postsynaptic potentials, and smaller fAHP. An LTS neuron is characterized by a short burst in the first 2-3 spikes, wider half-width, and smaller fAHP of action potentials. FS cells exhibit significantly larger fAHP and shorter halfwidth than those of RS and LTS neurons.

LTP and basal synaptic transmission recordings. Coronal hippocampal slices $(400 \mu \mathrm{m})$ were prepared in accordance with NIH guidelines. Briefly, hippocampal slices were cut using a vibrating blade microtome (Leica VT1000S) in ice-cold slicing buffer containing the following (in mM): 250 sucrose, $2.5 \mathrm{KCl}, 1.25 \mathrm{NaH}_{2} \mathrm{PO}_{4}, 26 \mathrm{NaHCO}_{3}, 0.5 \mathrm{CaCl}_{2}, 4.0$ $\mathrm{MgCl}_{2}$, and $10 \mathrm{D}$-glucose bubbled with $95 \% \mathrm{O}_{2}$ and $5 \% \mathrm{CO}_{2}$. Slices were then transferred to a holding chamber with oxygenated ACSF containing the following (in mM): $125 \mathrm{NaCl}, 2.5 \mathrm{KCl}, 1.25 \mathrm{NaH}_{2} \mathrm{PO}_{4}, 2 \mathrm{CaCl}_{2}, 1$ $\mathrm{MgCl}_{2}, 26 \mathrm{NaHCO}_{3}$, and $10 \mathrm{D}$-glucose for $30 \mathrm{~min}$ at $34^{\circ} \mathrm{C}$ and for another $30 \mathrm{~min}$ at $22^{\circ} \mathrm{C}$ for recovery and then transferred to a submersion recording chamber continually perfused with $32^{\circ} \mathrm{C}$ oxygenated ACSF (rate: $2 \mathrm{ml} / \mathrm{min}$ ). Slices were equilibrated for at least $15 \mathrm{~min}$ before each recording.

Field recording. ACSF-filled glass electrodes (resistance $<1 \mathrm{M} \Omega$ ) were positioned in the stratum radiatum of area CA1 for extracellular recording, as described previously (Tang et al., 2009). Synaptic responses were evoked by stimulating Schaffer collaterals with $0.1 \mathrm{~ms}$ pulses with a bipolar tungsten electrode (WPI) once every $20 \mathrm{~s}$. The stimulation intensity was systematically increased to determine the maximal field EPSP (fEPSP) slope and then adjusted to yield $40-60 \%$ of the maximal fEPSP slope. Experiments with maximal fEPSPs of $<0.15 \mathrm{mV}$ or with substantial changes in the fiber volley were rejected. After recording of a stable baseline for at least $15 \mathrm{~min}$, LTP was induced by 4TBS ( 4 bursts, each of 4 pulses at $100 \mathrm{~Hz}$ ). Field EPSPs were recorded (Axopatch 200B amplifier; Molecular Devices), filtered at $2 \mathrm{kHz}$, digitized at $10 \mathrm{kHz}$ (Axon Digidata 1321A), and stored for offline analysis (Clampfit 10). Initial slopes of fEPSPs were expressed as percentages of baseline averages. In summary graphs, each point represents the average of three consecutive responses. The time-matched, normalized data were averaged across experiments and are expressed as means \pm SEM.

\section{Mouse embryonic ex vivo hippocampal neuronal culture}

For the ex vivo study of neuronal development, primary dissociated hippocampal cultures were prepared from individual WT and NRG1-IV/ NSE-tTA mouse embryos on embryonic day 18 (E18). Each culture was derived from the hippocampi of a single embryo as described previously (Lesuisse and Martin, 2002) with minor modifications as follows. Dissociated hippocampal cultures were resuspended in supplemented DMEM and plated at a density of 100,000 cells/well on poly-D-lysine/laminincoated glass coverslips (BD Biosciences). The following day, the medium was replaced with Neurobasal/B27 medium, half of which was replaced weekly with fresh medium. At 1,7 , or $17 \mathrm{~d}$ in vitro (DIV), the neurons were transfected with plasmid DNA pVenus-YFP (Nagai et al., 2002) using Lipofectamine (Invitrogen) as per the manufacturer's protocol. Two to $3 \mathrm{~d}$ after transfection, neurons were fixed in $4 \%$ paraformaldehyde/4\% sucrose in PBS and immunostained using an antibody against GFP (Santa Cruz Biotechnology). Images were acquired using a Zeiss inverted LSM700 confocal with 10, 20, and $63 \times$ objectives to visualize dendrites, axons, and spines, respectively. Confocal images of neurons were collected through a series of five to eight $z$-sections collapsed to make $2 \mathrm{D}$ projections for image analysis. Dendrite and axon length andsoma size were traced and quantified using ImageJ software. Quantification was performed on $\geq 25$ neurons/genotype prepared from at least 2 embryos/genotype at DIV 3, 10, or 20 for axonal/soma, dendritic, or spine measurements, respectively. Sholl analysis was performed using the Sholl analysis plugin of ImageJ, with a radius step size of $5 \mu \mathrm{m}$. Spine density measurements were analyzed manually on $\geq 100 \mu \mathrm{m}$ segments from three secondary dendrites from 10-15 neurons/genotype and ex- pressed as the average number of spines per micrometer length of dendrite. All imaging and quantification was performed by a researcher blinded to genotype.

NCGC00168114 (IC87114) synthesis

NCGC00168114 (IC87114) synthesis was described previously in detail (Law et al., 2012).

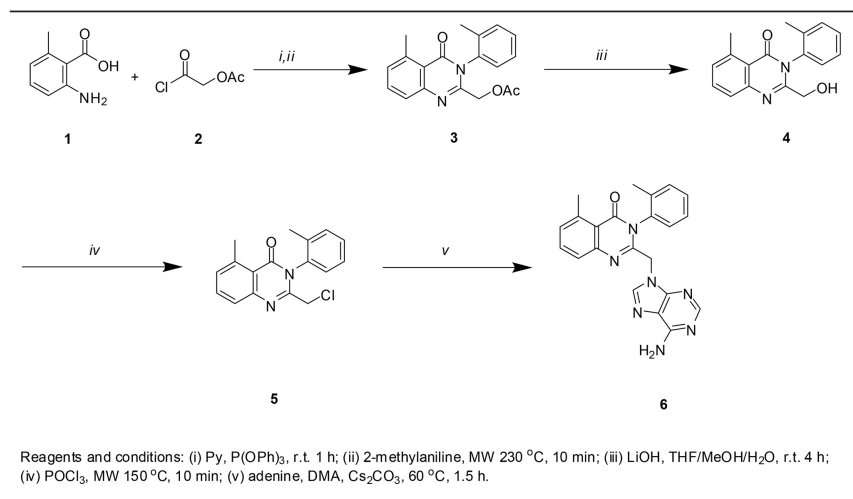

(iv) $\mathrm{POCl}_{3}, \mathrm{MW} 150^{\circ} \mathrm{C}, 10 \mathrm{~min}$; (v) adenine, $\mathrm{DMA}, \mathrm{Cs}_{2} \mathrm{CO}_{3}, 60^{\circ} \mathrm{C}, 1.5 \mathrm{~h}$.

IC87114 preclinical testing in the PPI, temporal order recency discrimination, and sociability tasks

For examination of the effects of IC87114, a separate naive cohort of animals was used for each behavioral task at 3 months of age. Each genotype group was split into two and randomly assigned a single intraperitoneal injection of $0.1 \mathrm{mg} / \mathrm{kg}$ IC87114 compound or vehicle control (0.25\% DMSO in physiological saline). IC 87114 was dissolved in $0.25 \%$ DMSO in physiological saline (vehicle) and injected intraperitoneally in a volume of $10 \mathrm{ml} / \mathrm{kg}$ body weight. Vehicle-treated mice were injected with the same volume of $0.25 \%$ DMSO in physiological saline. The 0.1 $\mathrm{mg} / \mathrm{kg}$ dose was originally chosen based on in vitro studies of the $\mathrm{IC}_{50}$ value of IC87114 (100 nM), in which IC87114 inhibits p110 $\delta$ with high selectivity in the range of 0.1-10 $\mu \mathrm{M}$ (Knight et al., 2006; Law et al., 2012) and corresponds to weight-equivalent doses for efficacy of the atypical antipsychotic haloperidol. Our initial preclinical data (Law et al., 2012) demonstrated that IC87114 $(0.1 \mathrm{mg} / \mathrm{kg})$ reduced hyperactivity induced by amphetamine in the mouse and PPI deficits in a rat neurodevelopment model of schizophrenia (Law et al., 2012). Moreover, our result was observed with a dose that had no effect on rodent spontaneous locomotor activity (Law et al., 2012), which is in contrast to that seen with other antipsychotic drugs, which cause hypokinesia and catelepsy (Ogren and Goldstein, 1994; O'Neill and Shaw, 1999). For assessment of the effects of IC87114 on PPI, 30 min before the start of startle/PPI testing, each genotype group was split into two and randomly assigned drug or vehicle control. For assessment of the effects of IC87714 on temporal order discrimination memory, 30 min before the "test phase," each genotype group was split into two, randomly assigned to drug or vehicle control, and tested as described above. For assessment of the effects of IC87714 on social cognitive behaviors, 10 min before the habituation phase (30 and $40 \mathrm{~min}$ before the sociability and social preference testing phases, respectively), each genotype group was randomly assigned to receive drug or vehicle control.

\section{Quantitative RT-PCR}

To assess NRG1-IV and NRG1 isoforms I-III quantitatively in several brain regions and across development, total RNA was extracted from hippocampus, PFC, and striatum of male NRG1-IV-overexpressing mice or WT littermate control mice at postnatal days 0 (PFC samples only), 6, 9, 13, and 100 using the TRIzol extraction method (QIAGEN). Firststrand cDNA was synthesized from $2 \mu \mathrm{g}$ of total RNA in a $20 \mu \mathrm{l}$ reaction volume using the High-Capacity cDNA Reverse Transcription Kit with Random Primers according to the manufacturer's protocol (Life Technologies). Quantitative RT-PCR was performed as described previously (Law et al., 2006). Levels of human NRG1-IV were assessed using custom primers and internal TaqMan probes (Life Technologies) designed spe- 
cifically to detect the unique NRG1-IV exon E187 as described previously (Law et al., 2006). To examine mRNA levels of endogenously expressed NRG1 isoforms, custom SYBR (NRG1-I and NRG1-II) and custom TaqMan (NRG1-III) RT-qPCR assays were designed to detect the murine equivalent of the human 5' exon-specific NRG1-I-III assays described previously (Law et al., 2006). Details of assay sequences are available upon request. For each sample, the expression levels of the gene of interest (GOI) were normalized to that of the housekeeping gene (HKG) GAPDH (Mm99999915_g1; Life Technologies). Expression data are presented as $1 /$ delta $^{\mathrm{CT}}$ using the following calculation: $1 /(\mathrm{CT}$ GOI-CT $\mathrm{HKG}$ ).

\section{Immunoblotting}

Fresh frozen $\mathrm{mPFC}$ was homogenized with a sonicator (Ultrasonic Processor Model GE50, Sonics) in a lysis buffer containing DTT $1 \mathrm{M}$ (dithiothreitol; Sigma-Aldrich), protease inhibitor mixture, and T-PER protein extraction (Thermo Scientific). Samples were incubated for $30 \mathrm{~min}$ on ice and centrifuged at $13,000 \mathrm{rpm}$ for $3 \mathrm{~min}$ at $4^{\circ} \mathrm{C}$. The supernatant was collected and frozen. Protein concentration was measured using a BCA protein assay kit (Thermo Scientific). Next, $25 \mu \mathrm{g}$ of protein was loaded into a gel and, after running, transferred onto PVDF membranes (Invitrogen Life Technology). The following primary antibodies were diluted in 5\% milk in Tris-buffered saline $+1 \%$ Tween 20 : anti-AKT-1 (1:500; Millipore; \#07-416), anti-pAKTser473 (1:50; Millipore; \#05-669-K), anti-pAKTthr308 (1:1000; Cell Signaling Technology; \#2965), antimTOR (1:1000; Cell Signaling Technology; \#2972), anti-pmTOR (1: 1000; Cell Signaling Technology; \#2971), anti-S6 (1:1000; Cell Signaling Technology; \#2317), anti-pS6 (1:2000; Cell Signaling Technology; \#4858), anti-p1108 (A-8 1:500; Santa Cruz Biotechnology, \#sc-55589), anti-NMDAR1 (H-300 1:200; Santa Cruz Biotechnology; \#sc-9058), anti-PSD95 (1:1000; Cell Signaling Technology; \#2507), anti-ErbB4 (C-18 1:500; Santa Cruz Biotechnology; \#sc-283), anti-pErbB4 (Tyr1056 1:500; Santa Cruz Biotechnology; \#sc-33040), anti-pErbB3 (tyr1289 1:1000; Cell Signaling Technology; \#4791), and anti- $\beta$-actin-peroxidase (1:25000, Sigma-Aldrich \#A3854). HRP-conjugated secondary antibodies (Santa Cruz Biotechnology) against mouse and rabbit were used at a 1:5000 dilution. Chemiluminescence was developed using a Flourochem Q image analyzer (Cell Biosciences). The optical density of the protein bands was calculated using ImageJ software. Total protein levels were normalized to the respective $\beta$-actin derived from the same blot and phosphorylated protein levels normalized to the respective total protein.

\section{Statistical analysis}

All statistical comparisons were performed using the SPSS statistics package version 22. Independent-samples $t$ tests were used to analyze the effect of genotype on measures of general health and performance in the temporal order object recognition, object location, and novel object task. General linear model (GLM) multivariate ANOVA was used to compare data from sensorimotor gating and GLM repeated-measures (RM) ANOVA was used for sociability data analysis. All behavioral data in which drug treatment was assessed were analyzed with either GLM multiple ANOVA or GLM RM-ANOVA according to the task and as described above, with genotype and treatment as between-subject factors. Sholl dendritic analysis was analyzed with GLM RM-ANOVA with genotype as the between-subject factor. Fisher's least significant difference (LSD) post hoc tests were used to investigate significant interactions. In vitro electrophysiology and in vivo biochemical Western blotting data were examined using an independent-samples $t$ test. All data are presented as means \pm SEM. All available animals and samples were included for statistical analysis unless otherwise noted. Experimenters were blinded to genotype or drug treatment during behavioral and electrophysiological testing and data analysis.

\section{Results}

Generation of NRG1-IV/NSE-tTA transgenic mice, general health screening, and NRG1 types I-IV expression profiling in brain

To determine the in vivo neurobiological consequences of NRG1-IV overexpression, transgenic mice genetically engineered
Table 1. Physical characteristics, motoric abilities, sensory reflexes, and empty cage behavior displayed by founder line \#6 mice

\begin{tabular}{|c|c|c|}
\hline General health & WT & NRG1-IV/NSE-tT \\
\hline Body weight (g) & $31.7 \pm 1.1$ & $30.9 \pm 0.5$ \\
\hline Poor coat condition (\%) & 0 & 0 \\
\hline Bald patches (\%) & 8 & 0 \\
\hline Missing whiskers (\%) & 0 & 7 \\
\hline Piloerection (\%) & 0 & 0 \\
\hline Body tone (\% of good) & 100 & 100 \\
\hline Limb tone (\% of good) & 100 & 100 \\
\hline Physical abnormalities (\%) & 0 & 0 \\
\hline \multicolumn{3}{|l|}{ Motoric abilities } \\
\hline Trunk curl (\%) & 100 & 100 \\
\hline Forepaw reaching (\%) & 100 & 100 \\
\hline Wire hang (s) & $56.4 \pm 2.5$ & $55.4 \pm 2.8$ \\
\hline Positional passivity (\%) & 0 & 14 \\
\hline \multicolumn{3}{|l|}{ Reflexes (\% of mice normal) } \\
\hline Righting reflex (\%) & 100 & 100 \\
\hline Corneal (\%) & 100 & 100 \\
\hline Ear twitch (\%) & 100 & 100 \\
\hline Whisker twitch (\%) & 100 & 100 \\
\hline Reactivity to handling (3-point scale) & $2.0 \pm 0.0$ & $2.0 \pm 0.0$ \\
\hline Petting escape (\%) & 42 & 29 \\
\hline \multicolumn{3}{|l|}{ Empty cage behavior } \\
\hline Transfer freezing (\%) & 0 & 0 \\
\hline Wild running (\%) & 0 & 0 \\
\hline Exploration (3-point scale) & $2.0 \pm 0.0$ & $2.0 \pm 0.0$ \\
\hline Grooming (s) & $1.5 \pm 0.5$ & $2.5 \pm 0.7$ \\
\hline Grooming (no. of events) & $0.7 \pm 0.2$ & $0.9 \pm 0.3$ \\
\hline Rearing (no. of events) & $20.4 \pm 1.6$ & $20.1 \pm 1.7$ \\
\hline Digging (no. of events) & $12.9 \pm 1.8$ & $11.7 \pm 2.3$ \\
\hline
\end{tabular}

NRG1-IV/NSE-tTA mice were indistinguishable from their control littermates on all general health parameters measured. All $p$-values $>0.27$. Data are shown as means \pm SEM or as percentages. $n=14$ WT and $n=12$ NRG1-IV. Similar findings were observed for founder line \#13 mice (data not shown).

to express human NRG1-IV under the NSE promoter were created (GenBank accession no. EF372273; Tan et al., 2007; Fig. $1 A-C)$. Because transgenes are randomly inserted into the genome, we tested two independent lines of NRG1-IV/NSE-tTA mice derived from different founders (founder line \#6 and founder line \#13), providing independent replication data for positive observations. Overall, NRG1-IV/NSE-tTA mice did not differ from WT mice in a comprehensive screen of general health measures or physical abilities (Table 1) and were born in the expected Mendelian frequency.

Quantitative molecular characterization of the NRG1-IV/ NSE-tTA mouse brain revealed that NRG1-IV transgene expression was observed at high levels in the hippocampus, $\mathrm{mPFC}$, and striatum (Fig. 1C) and was stable across development (Fig. 1C). In addition, compensatory changes in mouse endogenous NRG1 types I-III were not observed in the context of human NRG1-IV expression in any brain region examined (Fig. 1D-F). Furthermore, in contrast to previous overexpression models of NRG1 (Deakin et al., 2009) in which transgene expression was observed to be up to 100- to 1000-fold higher than endogenous physiological levels, NRG1-IV/NSE-tTA mice express human NRG1-IV at levels comparable to that of endogenous mouse NRG1 types I and III in all brain regions examined (Fig. $1 D-F$ ).

\section{Attenuated prepulse inhibition of the startle reflex (PPI), temporal order discrimination, and object location memory in NRG1-IV/NSE-tTA mice}

PPI is a measure of inhibitory sensorimotor gating of the startle response that can be studied experimentally in rodents (Papaleo et al., 2008, 2012; Powell et al., 2012; Moore et al., 2013), is atten- 
A
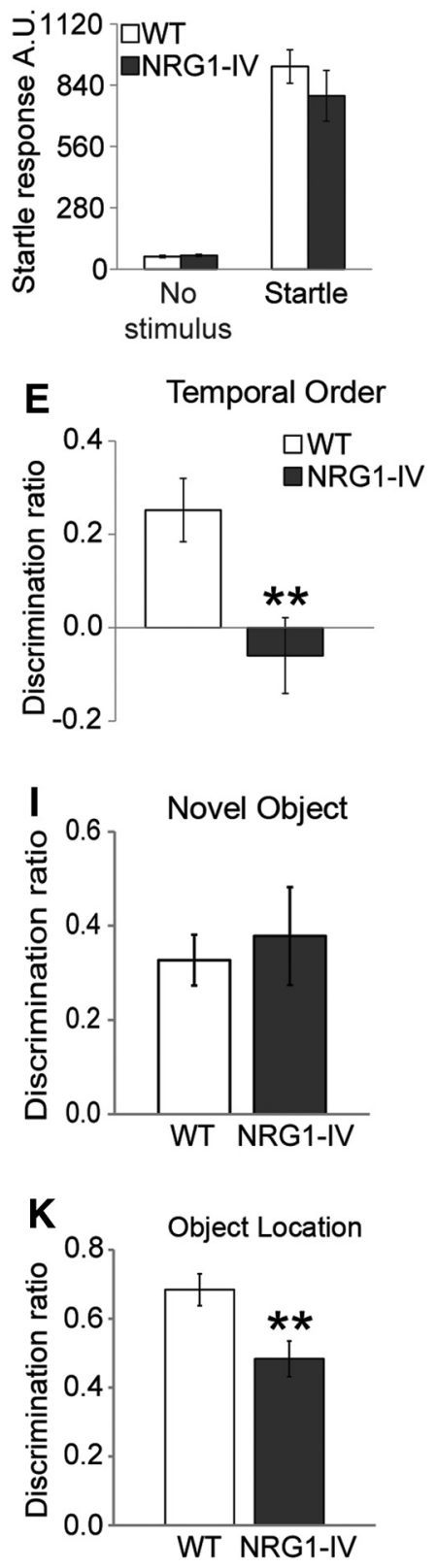

B

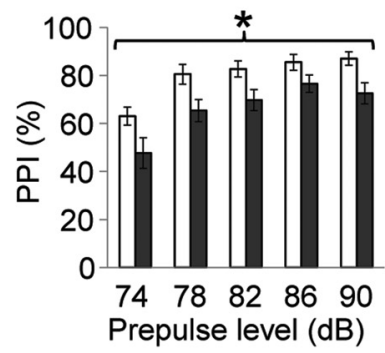

$\mathbf{F}$
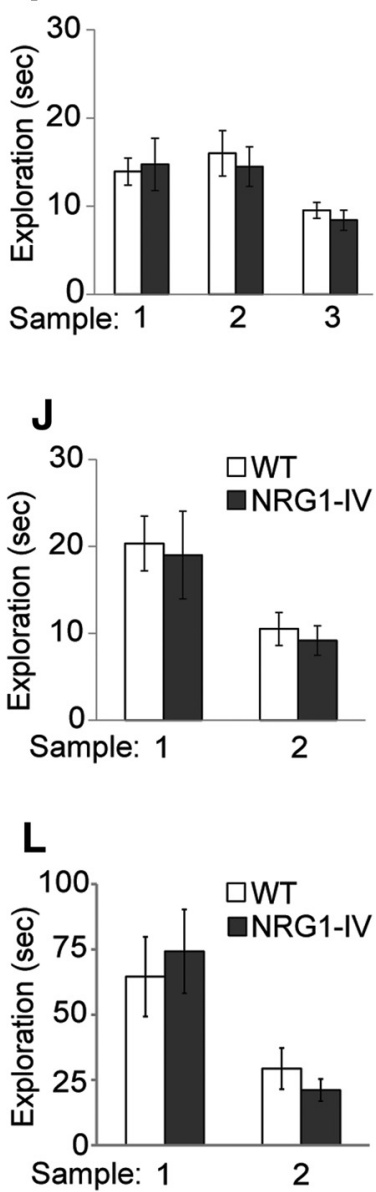

C
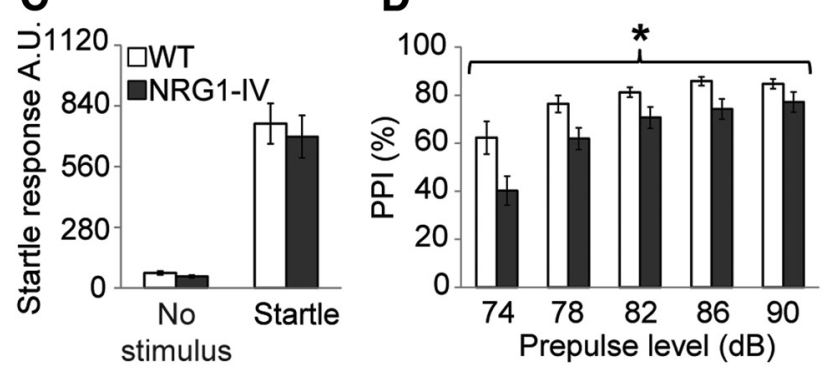

G Temporal Order
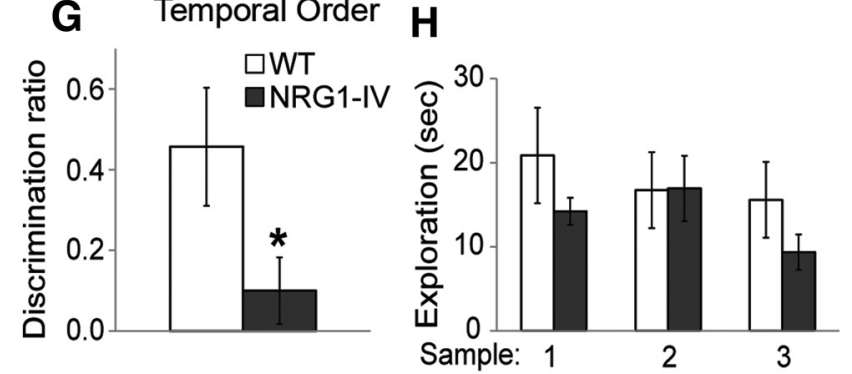

M
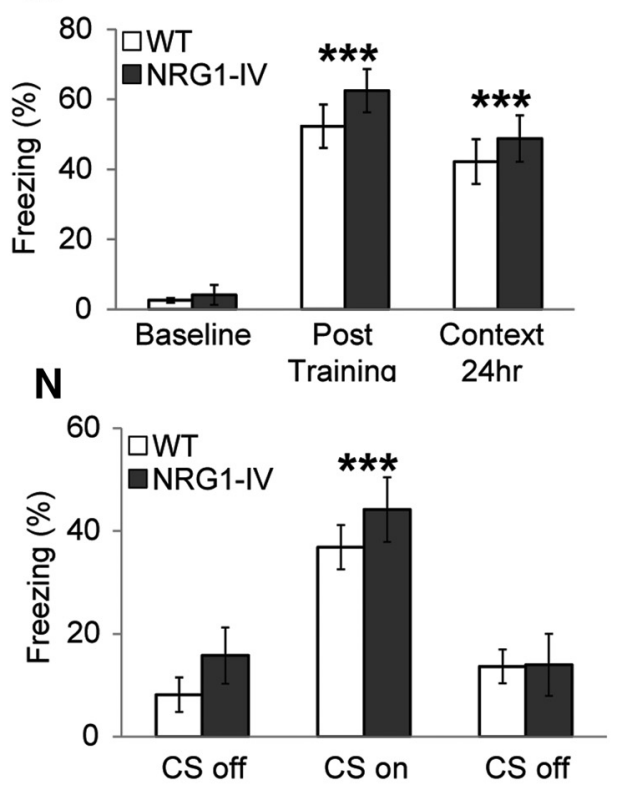

Figure 2. Impaired prepulse inhibition of startle response (PPI), temporal order discrimination, and object location memory in NRG1-IV/NSE tTA mice. A, C, Startle amplitude displayed by WT and NRG1-IV/NSE-tTA mice (\#6 and \#13, respectively) after the presentation of a $120 \mathrm{~dB}$ stimulus. $\boldsymbol{B}, \boldsymbol{D}$, Percentage prepulse inhibition of the acoustic startle response displayed by the same mice after the presentation of prepulse ( $n=12$ WT and $n=19$ NRG1-IV; founder line\#6 and $n=10$ WT and $n=18$ NRG1-IV; founder line\#13). GLM MANOVA. Variances were statistically significant between genotype groups ( ${ }^{*} p<0.05$ ) and between prepulse level (db; $p<0.0001$, both lines). $E$, $G$, Discrimination ratio displayed by NRG1-IV/NSE-tTA mice during the 5 min test phase (sample 3 ) of the temporal order object recognition task ( ${ }^{* *} p<0.001$ by Student's $t$ test; $n=15$ WT and $n=12$ NRG1-IV; founder line \#6 and ${ }^{*} p=0.003, n=7$ WT and $n=14$ NRG1-IV; founder line \#13). $\boldsymbol{F}, \boldsymbol{H}$, Total time spent exploring the objects presented during the 5 min sample phases 1,2 , and 3 . I, Discrimination ratio during the 5 min test trial of the novel object recognition task $(n=6$ WT and $n=$ 6 NRG1-IV; founder line \#6). J, Time spent exploring the 2 objects during the $10 \mathrm{~min}$ acquisition session and the $5 \mathrm{~min}$ test session of the novel object recognition test. $\boldsymbol{K}$, Discrimination ratio during the 5 min test trial of the object location task $\left({ }^{* *} p<0.01 ; n=9 \mathrm{WT}\right.$ and $n=8 \mathrm{NRG1-IV;}$; founder line \#6). $L$, Time spent exploring the 2 objects during the 10 min acquisition and the 5 min test session of the same object location test. $\boldsymbol{M}, \boldsymbol{N}$, Normal cued and contextual fear conditioning in NRG1-IV/NSE-tTA (founder line \#6 mice). $\boldsymbol{M}$, Freezing behavior prior to (baseline), subsequent to (posttraining), and $24 \mathrm{~h}$ after (context $24 \mathrm{~h}$ ) the cue-hock pairings. Both genotypes increased freezing subsequent to the CS-US pairings and the genotypes did not differ during the testing of contextual conditioning. $N$, Freezing behavior during testing for cued conditioning in the altered context without (CS off) and plus the auditory cue (CS on) displayed by WT and NRG1-IV littermates. GLM ANOVA showed that both genotypes increased their freezing behavior during the cue presentation. There was no effect of genotype on freezing either during the cue off or cue on phases of the experiment and there was no significant interaction between genotype and state of the cue ( $n=13 \mathrm{WT}$ and $n=13 \mathrm{NRG1-IV;}{ }^{* * *} p<0.0001$ CS off vs CS on for both genotypes). Data are shown as means \pm SEM.

uated in patients with schizophrenia and their siblings (Braff and Geyer, 1990; Braff et al., 2001; Kumari et al., 2005), and is widely used as a behavioral screening tool for antipsychotic drug potential (Powell et al., 2012; Moore et al., 2013). NRG1-IV/NSE-tTA mice did not differ in their acoustic startle reactivity to a $120 \mathrm{~dB}$ stimulus compared with WT littermates or in their levels of basal activity in the apparatus when no stimulus was presented (founder line \#6; Fig. 2A). However, PPI of a $120 \mathrm{~dB}$ acoustic startle stimulus 
was significantly impaired in NRG1-IV/NSE-tTA mice compared with WT at all prepulse levels $\left(F_{(1,29)}=5.33, p<0.03\right.$; Fig. $\left.2 B\right)$. For both genotypes, PPI progressively increased with higher prepulse intensity $\left(F_{(4,116)}=28.07, p<0.0001\right.$; Fig. $\left.2 B\right)$, demonstrating that both NRG1-IV/NSE-tTA and WT mice could discriminate between each prepulse. PPI deficits were consistently reproduced in mice derived from NRG1-IV/NSE-tTA founder line 13 (Fig. 2C,D). These findings demonstrate that genetic modification of NRG1-IV expression reproducibly impairs sensorimotor gating processing in a schizophrenia-like pattern and represents a molecular genetic model of the association between polymorphic variation in NRG1, including rs6994992, and PPI deficits in humans (Kéri et al., 2009; Greenwood et al., 2011).

Cognitive deficits, particularly those dependent on PFC and hippocampal function, are core features of schizophrenia, are associated with functional outcome in patients, and correlate with genetic background (Elvevåg and Goldberg, 2000). To assess whether overexpression of human NRG1-IV produces cognitive alterations and to evaluate specifically the neuroanatomical components involved, we tested NRG1-IV/NSE-tTA mice in a series of recognition memory tasks that test object familiarity (novel object preference), object spatial location (object-location test), and whether an object has been encountered before (temporal order discrimination memory test) (Barker and Warburton, 2011). Temporal order measures recency discrimination (Barker et al., 2007; Barker and Warburton, 2011) and rodent lesion and disconnection studies demonstrate that performance measured by this task is dependent on integrated information flow between the mPFC, perirhinal (PRH) cortex, and hippocampus (Barker et al., 2007; Barker and Warburton, 2011). Novel object preference requires intact function of the PRH cortex (but not the mPFC and the hippocampus) and object location is critically dependent on hippocampal function (Barker and Warburton, 2011). NRG1-IV/NSE-tTA mice exhibited significantly impaired performance in the temporal order recognition task compared with their WT littermates (founder line \#6; $t=2.97 ; \mathrm{df}_{25} ; p \leq 0.007$; Fig. 2E), with NRG1-IV/NSE-tTA mice failing to discriminate during the test phase. NRG1-IV/NSE-tTA and WT mice did not differ in the amount of exploration in the different phases of the task (Fig. 2F). Consistent phenotypes were observed for NRG1IV/NSE-tTA mice from founder line \#13 (Fig. 2G,H).

Next, we tested a separate naive cohort of NRG1-IV/NSE-tTA mice in the novel object preference test. During the test phase, the performance of NRG1-IV/NSE-tTA and WT littermates was equal (founder line \#6; Fig. $2 I, J$ ), indicating unimpaired object familiarity discrimination.

Finally, we tested a separate naive cohort of NRG1-IV/ NSE-tTA mice in the object location task. NRG1-IV/NSE-tTA exhibited significantly impaired task performance during the test phase (founder line $\# 6 ; t=2.902 ; \mathrm{df}_{15} ; p=0.01 ; \mathrm{Fig}$. $2 \mathrm{~K}$ ), but did not differ in their extent of exploration of the objects during the acquisition and test phases of the task (Fig. 2L). Specifically, WT mice spent more time exploring the misplaced object than the familiarly located object, whereas NRG1-IV/NSE-tTA mice spent an equal amount of time exploring both objects, indicating impaired spatial object location memory. Together, these data demonstrate that cognitive abilities relevant to $\mathrm{mPFC}$ and hippocampal function are impaired in the context of overexpression of NRG1-IV.

\section{Contextual and cued fear conditioning expression is unaltered in NRG1-IV/NSE-tTA mice}

To determine whether NRG1-IV affects associative learning and memory, we used a classical Pavlovian fear-conditioned task.
During fear conditioning training in founder line \#6 mice, both genotypes increased freezing subsequent to the CS-US pairings $\left(F_{(2,48)}=71.07, p<0.0001\right.$; Fig. $\left.2 M\right)$. NRG1-IV/NSE-tTA and WT mice did not differ in their degree of freezing either prior or subsequent to the CS-US pairings or during the testing of contextual conditioning $\left(F_{(1,24)}=1.41, p=0.25\right.$; Fig. $\left.2 N\right)$. Furthermore, there was no interaction between genotype and phase of training. During testing of cued conditioning, both groups increased freezing behavior during the cue presentation $\left(F_{(2,48)}=\right.$ $35.54, p<0.0001$; Fig. $2 N$ ), indicating association of the auditory cue with foot shock. No effect of genotype was observed on freezing either during the cue off or cue on phases of the experiment (Fig. $2 \mathrm{~N}$ ) and no interaction of genotype and state (on or off) of cue was observed. These data highlight that NRG1-IV overexpression did not impair fear conditioned learning and that its effects on learning and memory might be task specific.

\section{NRG1-IV/NSE-tTA mice display impaired social interaction behaviors}

Social interaction is a complex, mammalian-specific behavior (Amodio and Frith, 2006) that is fundamentally altered in schizophrenia and autism (Lee et al., 2004; Amodio and Frith, 2006; Howes and Murray, 2014; Maat et al., 2015). Although the neural correlates of social behavior in mice and humans are complex, recent evidence indicates a role for the $\mathrm{MPFC}$ and hippocampus (Lee et al., 2004; Amodio and Frith, 2006). We first tested NRG1IV/NSE-tTA founder line \#6 mice in the classic three-chamber paradigm test (Moy et al., 2004; Paterson and Law, 2014). No genotype effect $\left(F_{(1,24)}=2.46, p=0.12\right)$ or genotype $\times$ chamber time interaction was present in the sociability test. Both WT $\left(F_{(1,13)}=21.32, p<0.0005\right)$ and NRG1-IV/NSE-tTA mice $\left(F_{(1,11)}=11.33, p<0.01\right)$ spent more time in the chamber with the novel mouse than in the chamber with a novel object (Fig. $3 A)$. Similarly, time spent sniffing the novel mouse was greater than time spent sniffing the novel object for both WT $\left(F_{(1,13)}=\right.$ $39.0, p<0.0001)$ and NRG1-IV/NSE-tTA mice $\left(F_{(1,11)}=11.2\right.$, $p<0.01$; Fig. $3 B$ ). In contrast, a significant interaction of genotype and chamber was observed in the social novelty test $\left(F_{(1,24)}\right.$ $=4.96, p<0.05$; Fig. $3 C$ ). WT mice demonstrated a preference for the chamber containing the novel rather than the familiar mouse ( $p<0.001$; Fig. $3 C)$; absence of preference was observed in NRG1-IV/NSE-tTA mice ( $p=0.30$; Fig. $3 C$ ). Similarly, a significant interaction of genotype and sniffing time was observed $\left(F_{(1,24)}=4.08, p<0.05\right)$ in which WT mice spent more time sniffing the novel mouse $(p<0.0005$; Fig. $3 D)$; this was impaired in NRG1-IV/NSE-tTA mice $(p<0.05$; Fig. $3 D)$. Entries into the left and right side chambers did not differ between groups and no effect of genotype was observed (Fig. 3E). In NRG1-IV/NSE-tTA mice from founder line \#13, the test of sociability also revealed significant deficits (Fig. $3 F, G$ ) and consistent deficits were also observed for social novelty (Fig. $3 \mathrm{H}, \mathrm{I}$ ). These data indicate that NRG1-IV overexpression leads to social discrimination deficits in mice.

\section{Altered E/I balance in the mPFC of NRG1-IV/NSE-tTA mice} Given the evidence of mPFC-mediated behavioral dysfunction in NRG1-IV/NSE-tTA mice, we next examined the intrinsic firing and synaptic transmission properties of infragranular layer $\mathrm{V}$ pyramidal neurons and interneuron subtypes in the prelimbic mPFC. Lamina $V$ pyramidal neurons provide the principal efferents of the mammalian cortex to the striatum (Lévesque and Parent, 1998), receive dopaminergic input via the mesocortical projection path (Yang and Seamans, 1996), and altered prefrontal-mesostriatal macrocircuit function is proposed to be a key 

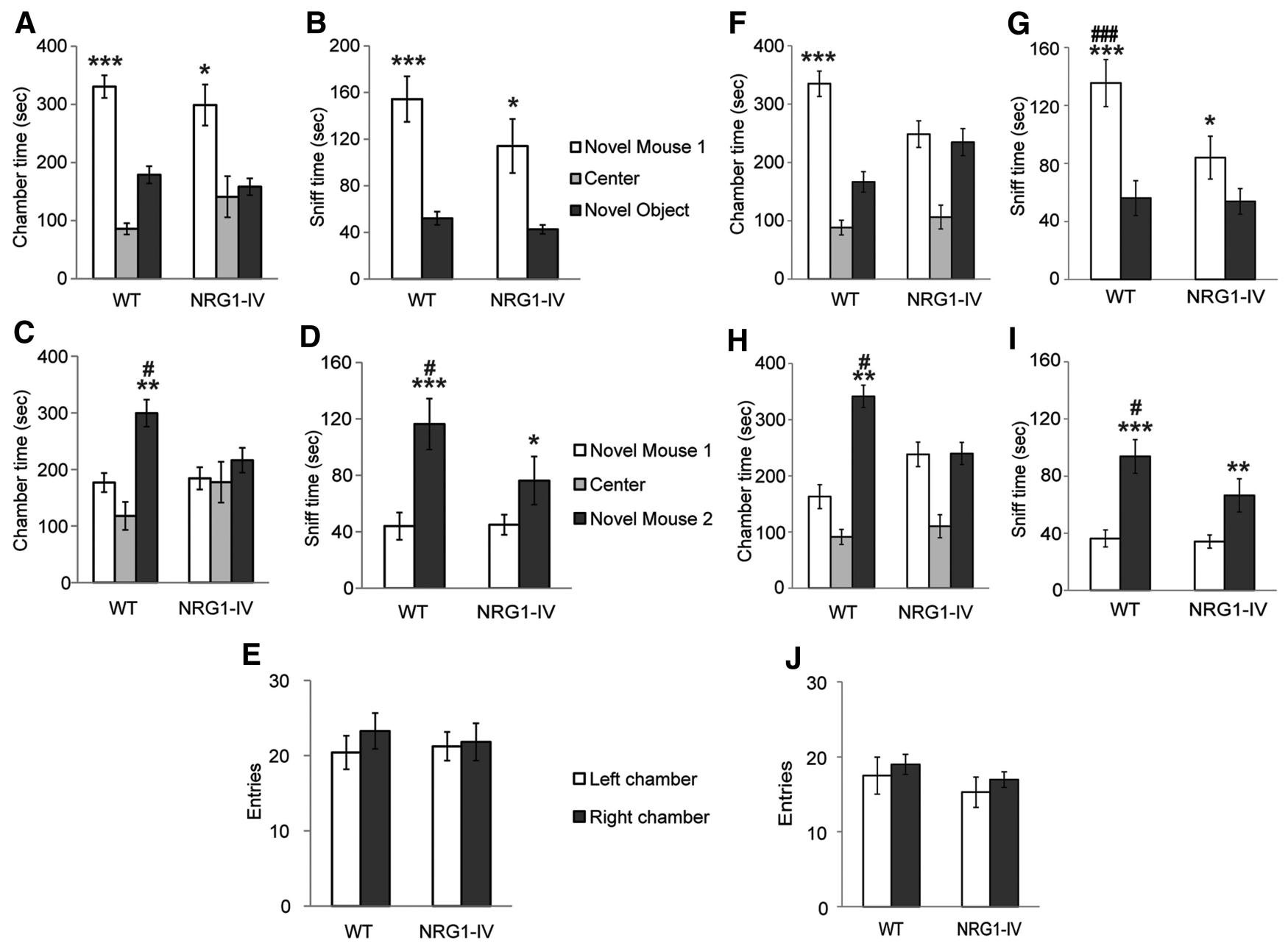

Figure 3. Impaired social interaction in NRG1-IV/NSE tTA mice. $A$, Time spent in the chamber with the novel mouse, in the chamber with the novel object, and in the empty center during the sociability test (founder line \#6). Variances were significantly different between chambers $(p<0.05)$. Effect significant in both WT $\left({ }^{* *} p<0.0005\right)$ and NRG1-IV/NSE-tTA $\left({ }^{*} p<0.01\right)$ mice. $B$, Time spent sniffing the novel mouse during the 10 min test for sociability was greater than time spent sniffing the novel object for both WT $\left.{ }^{* * * *} p<0.0001\right)$ and NRG1-IV/NSE-tTA $\left({ }^{*} p<0.01\right)$ mice. $C$, Time spent in the chamber with novel mouse 1 , in the side chamber with the novel mouse 2 , and in the center during the social novelty test. A significant genotype $\times$ chamber interaction was observed $(p<0.05)$. WT mice demonstrated a preference for the chamber containing the novel rather than the familiar mouse $\left({ }^{* *} p<\right.$ 0.005 ); absence of preference was observed in NRG1-IV/NSE-tTA mice. $D$, Similarly, a significant genotype $\times$ sniffing time interaction was observed $(p<0.05)$ in which WT mice spent more time sniffing the novel mouse $2\left({ }^{* * *} p<0.0005\right)$, which was impaired in NRG1-IV/NSE-tTA mice $\left({ }^{*} p<0.05\right)$. GLM RM-ANOVA and post hoc LSD \#p $<0.05$ versus the same measure in NRG1-IV/NSE tTA mice. $\boldsymbol{E}$, Entries into the left and right side chambers ( $n=14$ WT and $n=12$ NRG1-IV). $\boldsymbol{F}$, Time spent in the chamber during the sociability test (founder line \#13). A genotype $\times$ time spent in the chambers interaction was observed $(p<0.01)$. WT mice spent more time in the chamber with the novel mouse than in the chamber with the novel object $\left({ }^{* * *} p<0.0008\right)$, whereas NRG1-IV/NSE-tTA mice showed no preference $(p=0.74)$. G, Time spent sniffing each wire cage during the 10 min test for sociability. A genotype $\times$ sniff time interaction was observed $(p<0.05)$. Time spent sniffing the novel mouse was greater than time spent sniffing the novel object for WT $\left({ }^{* * *} p<0.0001\right)$ and marginally for NRG1-IV/NSE-tTA mice $\left({ }^{*} p<0.05\right)$. However, WT mice spent more time sniffing the novel mouse compared with NRG1-IV/NSE-tTA mice (\#\#\# $\left.<0.0005\right)$. $\boldsymbol{H}$, Time spent in the chambers during the social novelty test (founder line \#13). A genotype $\times$ chamber time interaction was observed $\left.{ }^{* *} p<0.005\right)$. WT mice spent more time in the chamber with the newly introduced novel mouse 2 than in the chamber containing the novel mouse $\left.1{ }^{* *} p<0.005\right)$. NRG1-IV/NSE-tTA mice failed to discriminate $(p=0.96)$. I, Time spent sniffing each wire cage during the $10 \mathrm{~min}$ test for preference for social novelty. Variances were significantly different between chambers $(p<0.05)$. More time sniffing the newly introduced novel mouse 2 than the novel mouse 1 was seen in WT $\left.{ }^{* * *} p<0.0005\right)$ and in NRG1-IV/NSE-tTA littermates $\left({ }^{* *} p<0.005\right)$. WT mice spent more time sniffing the newly introduced novel mouse 2 compared with NRG1-IV/NSE-tTA littermates $(\# p<0.05$ ). J, Number of entries into the side chambers displayed during the acclimatization phase did not differ between genotype. For $\boldsymbol{F}-\boldsymbol{J}, n=12$ WT and $n=21$ NRG1-IV. All analyses were by GLM RM-ANOVA. Data are shown as means \pm SEM.

contributor to working memory deficits in schizophrenia (AbiDargham et al., 2002; Winterer and Weinberger, 2004). Wholecell voltage-clamp recording in slice preparations from adult NRG1-IV/NSE-tTA mice revealed that layer V pyramidal neurons exhibited significant and selective decreases in the frequency of mEPSCs $(t=3.188 ; p=0.0029$; Fig. $4 A)$, with no change in the frequency of mIPSCs (Fig. 4B), indicating an impairment in presynaptic release probability or excitatory synaptic number. No significant genotype effect was observed for the amplitude of mEPSCs or mIPSCs (Fig. 4A,B), suggesting that NRG1-IV ex- pression did not alter density or conductance of postsynaptic receptors (Queenan et al., 2012). We next used whole-cell current-clamp recording to measure repetitive firing patterns in pyramidal neurons, LTS, RS, and FS interneurons (Fig. 4C-F) of $\mathrm{mPFC}$ slices from adult mice. Significant increases in lamina $\mathrm{V}$ LTS interneuron excitability were observed in NRG1-IV/NSEtTA mice $(t=2.112, p=0.04$; Fig. $4 D)$. In WT mice, LTS interneurons exhibited high input resistances, low threshold spikes, and prolonged plateau potentials in response to intracellular depolarization LTS (Fig. 4D). Firing frequency in LTS cells of 


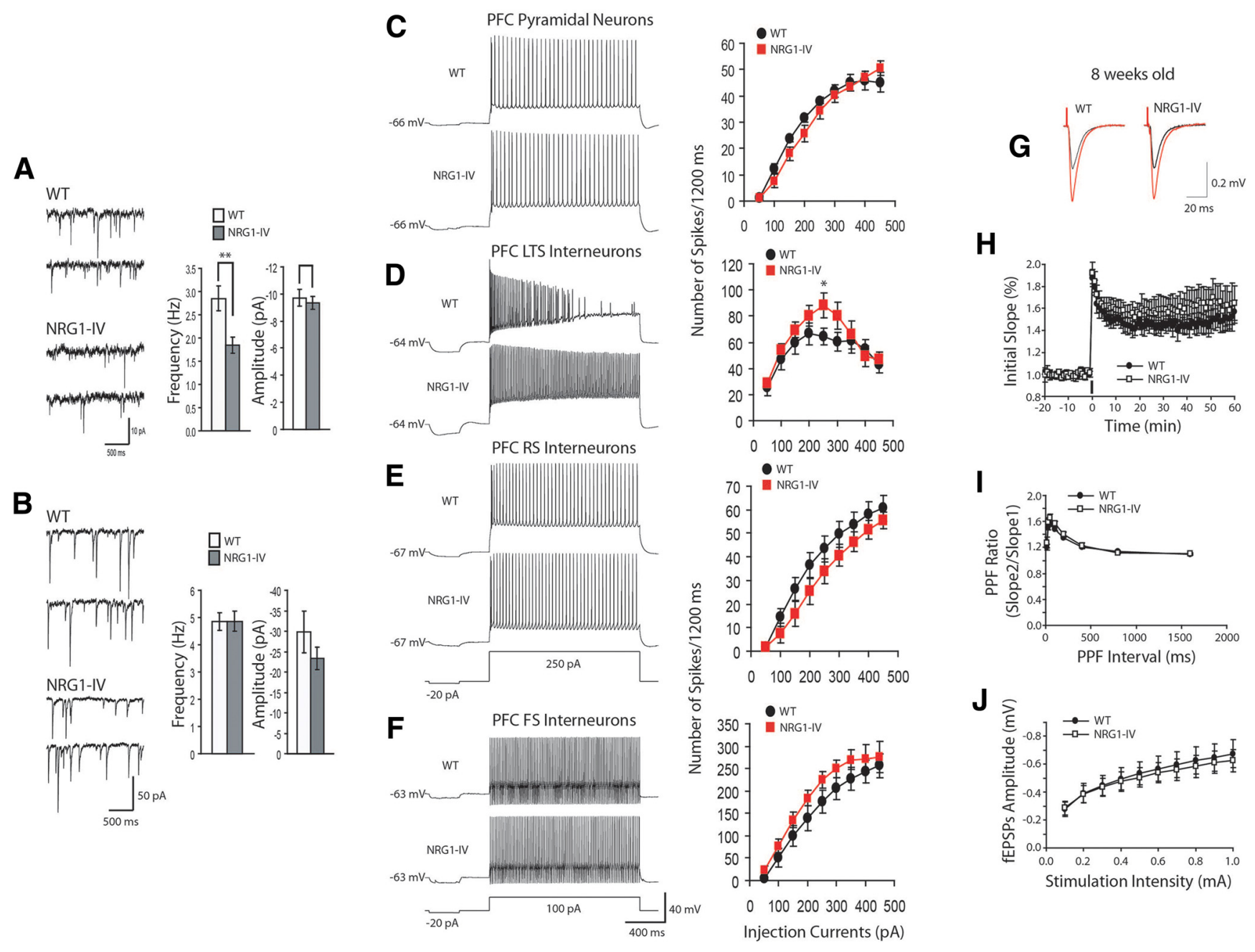

Figure 4. Decreased glutamatergic transmission and increased LTS interneuron excitability in layer V mPFC in NRG1-IV/NSE tTA mice. A, Sample traces and quantification of mEPSCS recorded from layer V pyramidal neurons from WT and NRG1-IV/NSE tTA mice. ( $n=4$ WT mice, 12 slices, 20 cells and $n=4$ NRG1-IV mice, 12 slices, 19 cells). Means were significantly different between genotypes $\left({ }^{* *} p=0.0029\right)$ by unpaired Student's $t$ test. $\boldsymbol{B}$, Sample traces and quantification of mIPSCs recorded from layer V pyramidal neurons of mPFC in NRG1-IV/NSE tTA mice ( $n=3$ WT mice, 10 slices, 16 cells and $n=4$ NRG1-IV mice, 11 slices, 18 cells). C $\boldsymbol{F}$, Repetitive firings were evoked by various depolarizing steps and action potential numbers were plotted against the depolarizing currents injected into neurons in layer $\mathrm{V}$ of $\mathrm{mPFC}$. Representative traces are shown on the left and quantifications on the right. C, Pyramidal neuron excitability ( $n=4$ WT mice, 11 slices, 11 cells and $n=4$ NRG1-IV mice, 12 slices, 12 cells). D, LTS neuron excitability. LTS interneurons were characterized by a short burst in the first $2-3$ spikes, wider half-width, and smaller fAHP of action potentials with very high input resistances. ( $n=4$ WT mice, 11 slices, 11 cells and $n=4$ NRG1-IV mice, 11 slices, 12 cells). Means were significantly different between genotypes ( $\left.{ }^{*} p=0.04\right)$, by unpaired Student's $t$ test. $\boldsymbol{E}$, RS interneuron excitability ( $n=3$ WT mice, 5 slices, 5 cells and $n=3$ NRG1-IV mice, 9 slices, 9 cells). $F$, FS interneuron excitability ( $n=3$ WT mice, 8 slices, 8 cells and $n=4$ NRG1-IV mice, 12 slices, 12 cells). Normal basal transmission and LTP of the hippocampus in adult NRG1-IV/NSE-tTA mice. G, $\boldsymbol{H}$, NRG1-IV/NSE-tTA mice display normal LTP. Example fEPSP recordings before (black lines) and 60 min after LTP induction (red lines) are shown in $\boldsymbol{G}$ and the complete time courses are shown in $\boldsymbol{I}$. Normal paired pulse facilitation (PPF). The ratios of the second and first EPSP slopes were calculated and mean values are plotted against different interpulse intervals (IPIs, $12.5-1600 \mathrm{~ms}$ ). J, Normal basal synaptic transmission in NRG1-IV/NSE-tTA mice. Input- output curves were generated by plotting the postsynaptic response (amplitude of fEPSP) as a function of the stimulation intensity. Data are shown as means \pm SEM.

NRG1-IV/NSE-tTA mice was nonadaptive and higher than that in WT neurons. No differences were observed in the excitability of pyramidal neurons, RS and FS interneurons (Fig. 4C,E,F). NPY/SOM/NOS-expressing interneurons have been identified as LTS interneurons, exhibit highly specific connectivity, and synapse onto the dendritic region of their targets (Beierlein et al., 2003).

The frequency of spontaneous (s)EPSCs in layer $V$ pyramidal neurons was markedly increased in NRG1-IV/NSE-tTA mice $(t=2.111, p=0.04$; Fig. $5 A, B)$. No significant differences were observed in the frequency of spontaneous EPSCs in layer $\mathrm{V}$ interneurons (LTS, RS, and FS) of NRG1-IV/NSE-tTA mice (Fig. $5 C-E)$. However, a trend for increases in the amplitude of sEPSCs was observed in FS interneurons (Fig. 5E).
Hippocampal LTP and basal synaptic transmission is normal in NRG1-IV/NSE-tTA mice

Previous studies have demonstrated a role for NRG1 in hippocampal LTP both in vivo and in vitro (Kwon et al., 2005; Chen et al., 2010; Agarwal et al., 2014), but the role of NRG1-IV is not known. We measured fEPSPs in the Schaffer collateral-CA1 circuit of acute hippocampal slices and found no impact of NRG1-IV transgene expression on hippocampal LTP or basal synaptic transmission (Fig. 4G-J).

\section{NRG1-IV regulates glutamatergic synapse maturation and plasticity in vitro}

NRG1 signaling via ErbB4 regulates synaptic maturation and plasticity (Fazzari et al., 2010; Wen et al., 2010; Mei and Nave, 
A

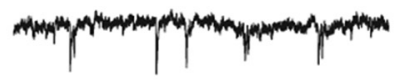

WT

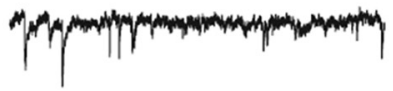

$10 \mathrm{pA}$

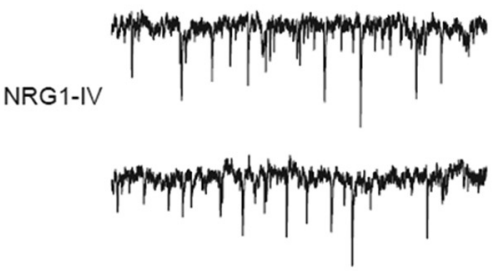

C

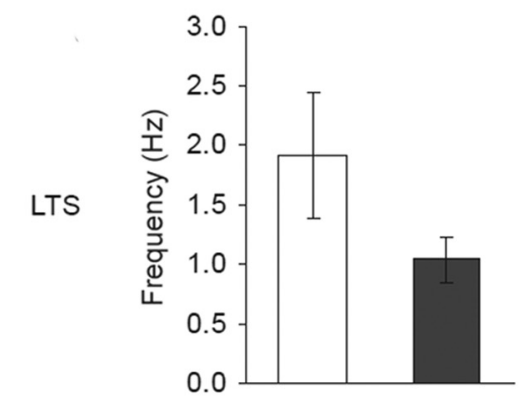

D

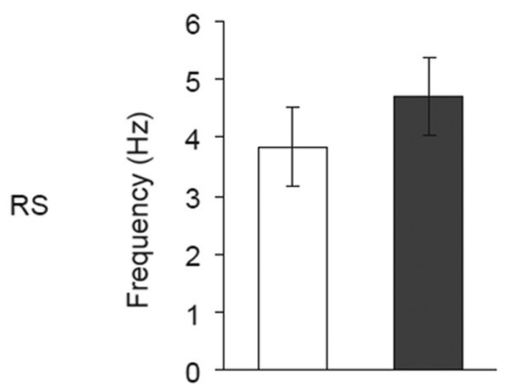

$\mathbf{E}$

LTS

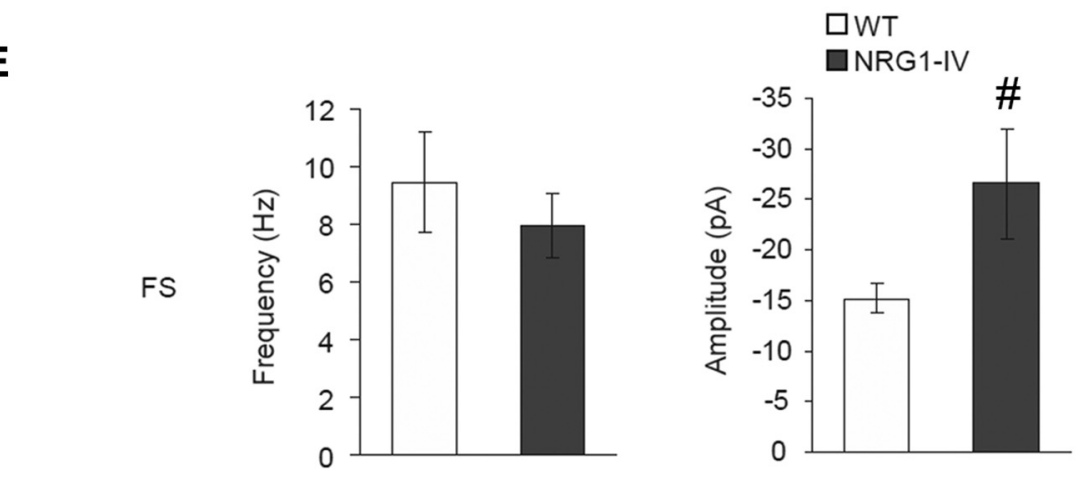

B

$\square$ wT

NRG1-IV
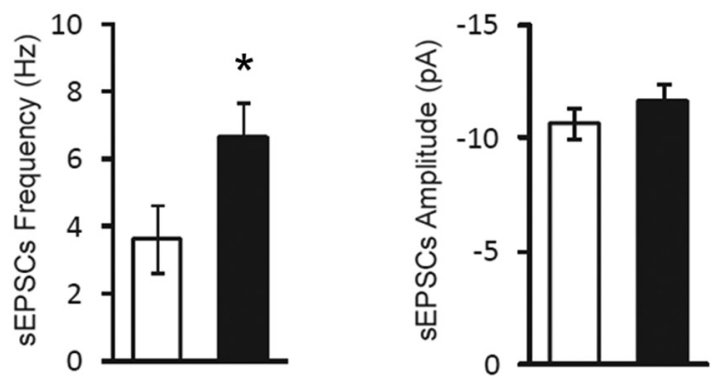
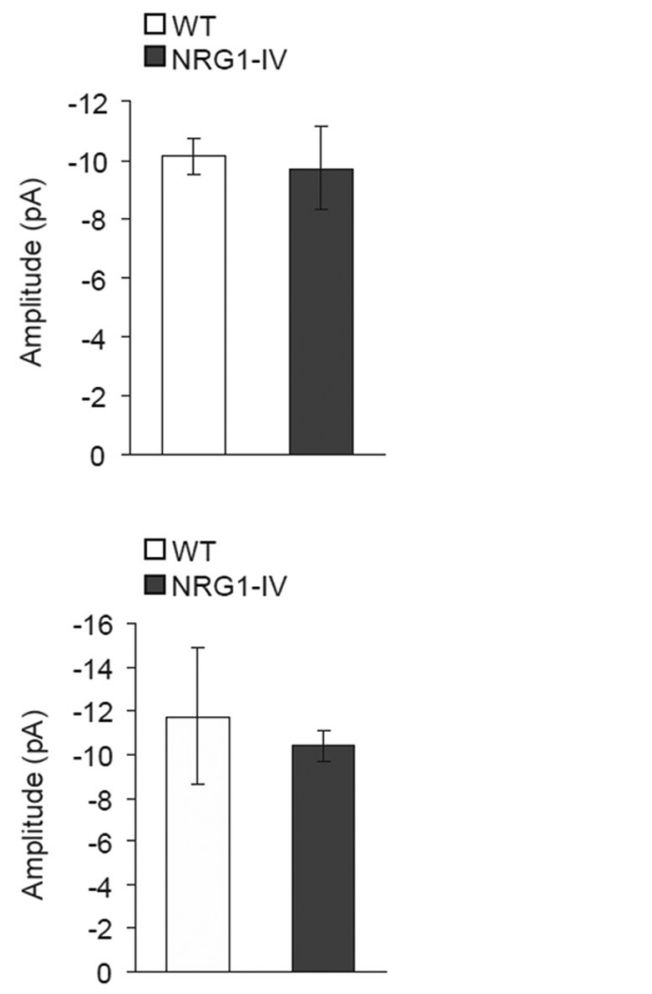

Figure 5. Spontaneous excitatory input to pyramidal neurons and interneurons in layer $\mathrm{V}$ of $\mathrm{mPFC}$. Whole-cell, voltage-clamp recordings were performed to record sEPSCs at $-70 \mathrm{mV}$ of holding potential in pyramidal neurons $(\boldsymbol{A}, \boldsymbol{B} ; n=4$ WT, 11 slices, 11 cells; NRG1-IV; $n=4,12$ slices, 12 cells); LTS interneurons $(\boldsymbol{C} ; n=4$ WT, 10 slices, 10 cells; NRG1-IV, $n=4,11$ slices, 11 cells; RS interneurons ( $\boldsymbol{D} ; n=3$ WT, 9 slices, 9 cells; NRG1-IV, $n=3,9$ slices, 9 cells; and FS interneurons $\left(\boldsymbol{E} ; n=3\right.$ WT, 8 slices, 8 cells; NRG1-IV, $n=4,10$ slices, 10 cells). ${ }^{*} p<$ $0.05 ; \# p=0.06$ by unpaired Student's $t$ test. Data are shown as means \pm SEM. 

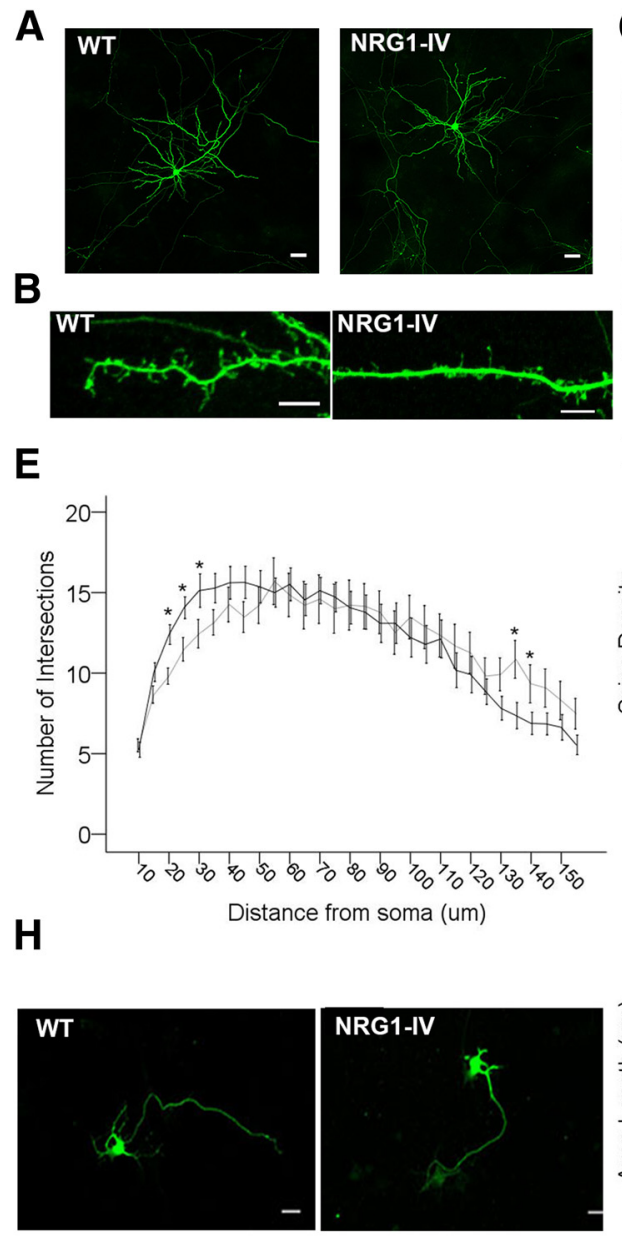

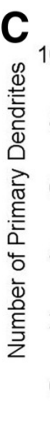

$F$

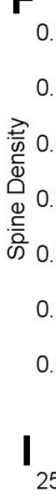

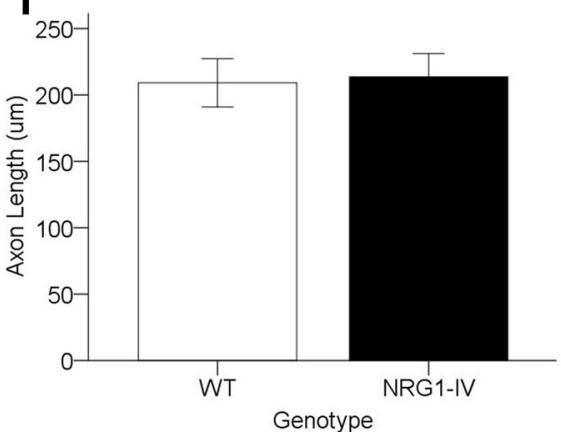

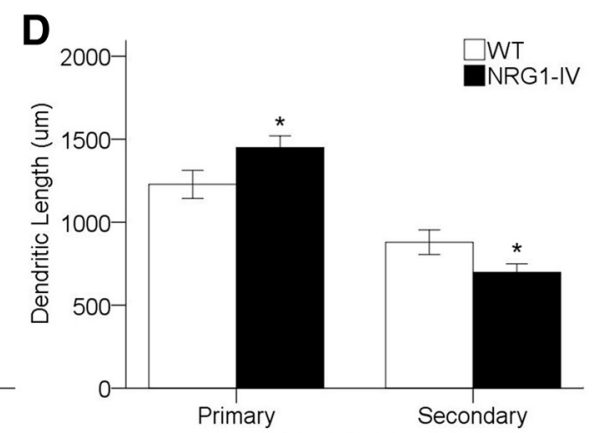

G
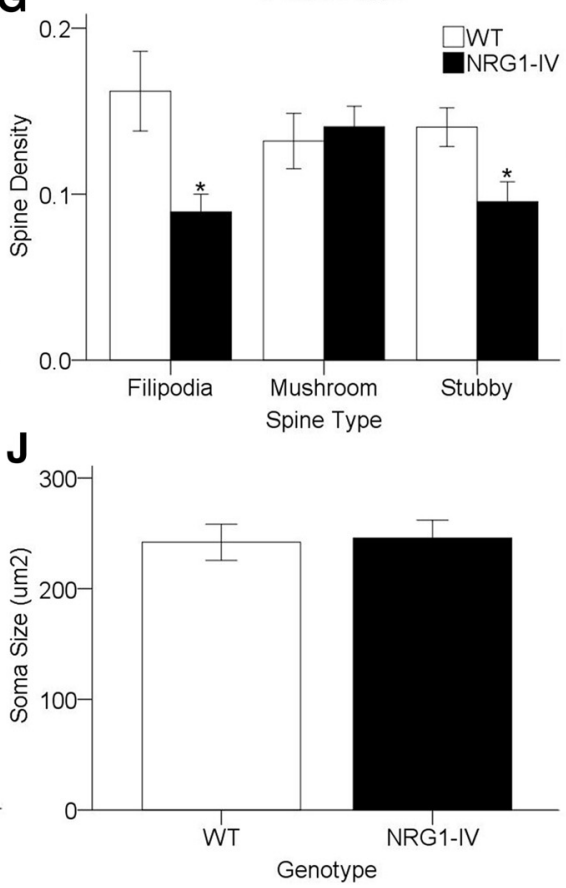

Figure 6. NRG1-IV affects neuronal morphology and dendritic spine development ex vivo. $\boldsymbol{A}$, Representative images of GFP-stained hippocampal neurons of E18, WT and NRG1-IV/NSE tTA mice at DIV 10. Scale bar, $50 \mu \mathrm{m}$. $\boldsymbol{B}$, Representative images of $63 \times$ magnification confocal images of dendritic segments from GFP-stained hippocampal neurons. Scale bar, $5 \mu$ m. $\boldsymbol{C}$, Primary dendrite number in hippocampal neurons cultured from NRG1-IV/NSE tTA embryos ( ${ }^{* * *} p<0.001$ by unpaired Student's $t$ test; $n=33$ neurons/genotype). $\boldsymbol{D}$, Primary and secondary dendrite length ( $n=$ 33 neurons/genotype). Variances were significantly different between genotypes, with NRG1-IV increasing primary dendrite length and decreasing secondary dendrite length ( ${ }^{*} p<0.05$ by unpaired Student's $t$ test). $\boldsymbol{E}$, Sholl analysis of the number of intersections at radii of $5 \mu \mathrm{m}$ intervals from the cell soma. NRG1-IV/NSE tTA neurons show an increased number of intersections at ranges close to the cell soma ( $\left.{ }^{*} p<0.05,20-30 \mu \mathrm{m}\right)$, but a reduced number of intersections at ranges distal to the soma ( ${ }^{*} p<0.05,135-140 \mu \mathrm{m} ; n=33$ neurons/genotype). $\boldsymbol{F}$, Spine density on secondary dendrites from DIV 20 hippocampal neurons is decreased in NRG1-IV/NSE tTA mice $\left({ }^{*} p<0.05\right.$, unpaired Student's $t$ test; $n=33$ dendritic segments per genotype). $\mathbf{G}$, Filipodia, mushroom, and stubby spine subtype densities ( $n=33$ dendritic segments per genotype). Variances were significantly different between genotypes ( ${ }^{*} p<0.05$ ). Analysis by GLM ANOVA with post hoc LSD. $\boldsymbol{H}-\boldsymbol{J}$, Axonal length and soma size were not affected by genotype. Data are shown as means \pm SEM.

2014). Dendritic spines are the primary sites for excitatory synapse formation and their dysregulation is thought to underlie many neuropsychiatric disorders, including schizophrenia, in which reduced spine density has been reported in the brain (Glantz and Lewis, 2000; Penzes et al., 2011). We prepared ex vivo primary hippocampal neuronal cultures from E18 NRG1-IV/ NSE-tTA mice and their WT littermates and transfected with pVenus-YFP at 1, 7, or 17 DIV. At 4, 10, and 20 DIV, neurons were fixed and assessed for axonal length, dendritic morphology, and spine density, respectively (Fig. 6A,B). Quantitative analysis demonstrated that NRG1-IV overexpression increased primary dendrite number $\left(t_{(58)}=-4.84 ; p<.001\right)$ and length $\left(t_{(58)}=\right.$ $-2.03 ; p<0.05$; Fig. $6 C, D)$ and decreased secondary dendrite length $\left(t_{(58)}=2.065, p<0.05\right.$; Fig. $\left.6 D\right)$. Consistently, Sholl analysis revealed that NRG1-IV expression significantly increased the number of neuritic intersections proximal to the soma (20-30 $\mu \mathrm{m} ; p<0.05)$ and decreased neuritic intersections distal to the soma (135-140 $\mu \mathrm{m} ; p<0.05$; genotype $^{\star}$ distance interaction; $F_{(29,1682)}=2.512, p<0.001$; Fig. $\left.6 E\right)$. Analysis of mature neurons (20 DIV) demonstrated that NRG1-IV significantly reduced spine density $\left(t_{(19)}=2.263, p<0.05\right.$; Fig. $\left.6 F\right)$. Spine density deficits were accounted for by a decreased density of filipodia $(p<0.05)$ and stubby spines $\left(p<0.05\right.$; spine type ${ }^{\star}$ genotype; $F_{(2,57)}=3.504, p<0.05$; Fig. $\left.6 G\right)$. Axonal length or soma size (Fig. $6 H-J$ ) were not affectyed by genotype. These data demonstrate that NRG1-IV overexpression alters dendritic aborization and reduces spine density and suggest that NRG1-IV is necessary for the formation and maturation of new spines.

\section{NRG1-IV regulates expression of ErbB4 and PI3K-AKT} pathway signaling

NRG1 signaling is involved in PSD95 organization, NMDA and AMPA receptor function, and downstream activation of AKT signaling (Hahn et al., 2006; Fazzari et al., 2010; Wen et al., 2010; 

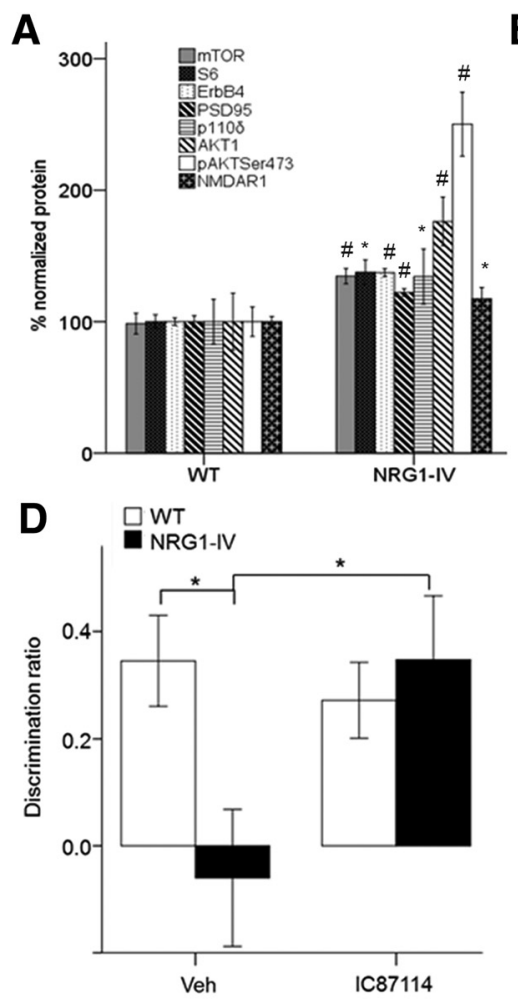

B

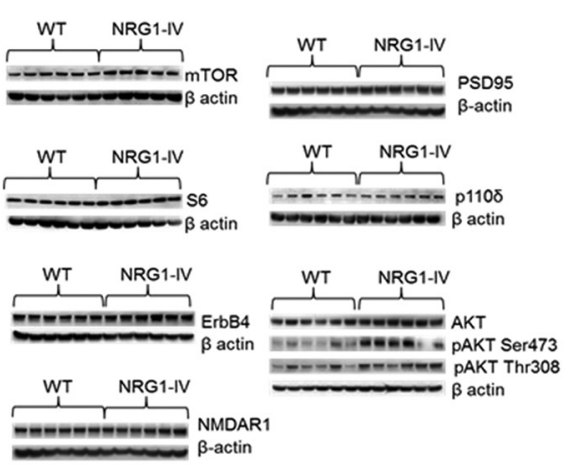

E

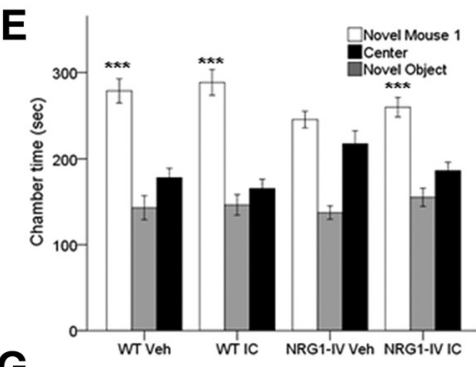

G

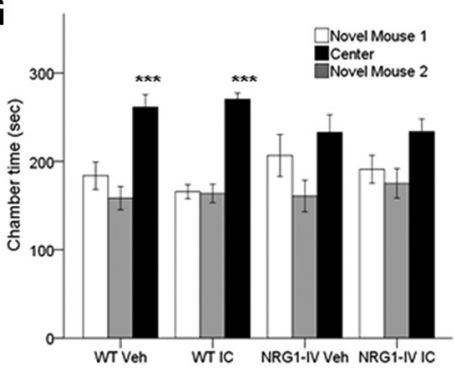

C
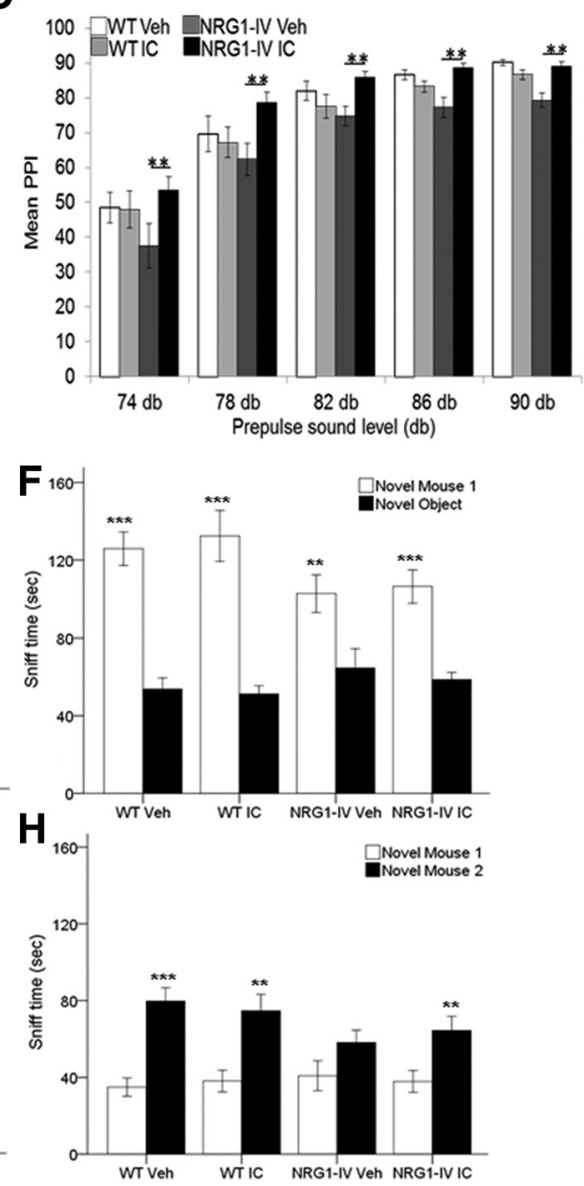

Figure 7. Preclinical relevance of PIK3CD signaling and pharmacological inhibition in NRG1-IV/NSE tTA mice. $A$, ErbB4, $\mathrm{p} 110 \delta$, and related NRG1 signaling proteins are increased in the mPFC of NRG1-IV/NSE tTA mice $\left({ }^{*} p<0.05\right.$; \# $p<0.01$, unpaired Student's $t$ test; $n=6$ WT and $n=5-6$ NRG1-IV). $B$, Western blots. C, Reversal of PPI deficits in NRG1-IV/NSE tTA mice with the PIK3CD inhibitor, IC87114 ( $n=13$ WT veh, $n=11$ WT IC, $n=11$ NRG1-IV veh, and $n=11$ NRG1-IV IC). There was a significant interaction between genotype and drug treatment: $(p=0.002)$ and a main effect of genotype ( $p=0.027$, GLM MANOVA). IC87114 treatment rescued NRG1-IV-dependent PPI deficits, significantly improving PPI in drug-treated NRG1-IV/NSE-tTA mice compared with vehicle-treated transgenic mice (db74-db90; ${ }^{* *} p<$ 0.005; by posthocLSD). No significant effect of drug on PPI was observed in WT mice. $D$, Intraperitoneal administration of IC $87114(0.1 \mathrm{mg} / \mathrm{kg}) 30 \mathrm{~min}$ beforethe test phase of the temporal order object recognition task ( $n=13$ WT veh, $n=10$ WTIC, $n=6$ NRG1-IV veh, and $n=9$ NRG1-IVIC). There was a significant interaction between genotype and drug treatment $(p=0.02)$. IC 87114 treatment rescued temporal order discrimination deficits found in NRG1-IV/NSE-tTA mice $\left({ }^{*} p<0.05\right)$. No effect of drug was evident in WT mice $(p>0.5)$. Again, a significant effect of genotype was confirmed on recency discrimination memory in vehicle-treated mice $\left({ }^{*} p<0.05\right)$. $\boldsymbol{E}-\boldsymbol{H}$, No significant effect of IC87114 treatment in NRG1-IV/NSE-tTA mice was observed in tests of sociability or social novelty. For each measure, a significant main effect of chamber was confirmed by GLM RM-ANOVA: $\boldsymbol{E}_{,} \boldsymbol{F}_{(1,54)}=55.861, p<0.001 ; \boldsymbol{F}_{,} \boldsymbol{F}_{(1,54)}=111.992, p<0.001 ; \boldsymbol{G}, F_{(1,54)}=20.179, p<0.001 ; \boldsymbol{H}, \boldsymbol{F}_{(1,54)}=79.834, p<0.001$. No main effect of treatment or treatment $\times$ genotype interactions was observed (WT Veh, $n=16$; WT IC $n=14$; NRG1-IV Veh, $n=14$; NRG1-IV IC, $n=14$ ). Post hoc LSD comparisons revealed that variances were significantly different between chambers (novel mouse vs novel object; $\boldsymbol{E}, \boldsymbol{F}$ ) and (novel mouse 1 vs novel mouse $2 ; \boldsymbol{G}, \boldsymbol{H}$ ). ${ }^{* *} p<0.01 ;{ }^{* * *} p<0.001$. Data are shown as means \pm SEM.

Mei and Nave, 2014). We next assessed a panel of select synaptic and intracellular proteins associated with NRG signaling and schizophrenia in mPFC lysates of NRG1-IV/NSE-tTA mice. NRG1-IV overexpression was associated with increases in ErbB4, p1108, PSD95, NMDAR1, AKT1, pAKT/ser473, mTOR, and S6 protein levels (Fig. $7 A, B$ ). No changes were observed for total ErbB2 or ErbB3, pAKT/Thr308, p70S6K, pmTOR, or GSK3 $\beta$, pGSK3 $\beta$ (data not shown). NRG1 signaling has also been shown to alter dopaminergic transmission (Kato et al., 2011). However, we observed no effects of NRG1-IV expression on levels of tyrosine hydroxylase $(\mathrm{TH})$ or $\mathrm{pTH}$ in the $\mathrm{mPFC}$, hippocampus, or striatum (data not shown). These biochemical data indicate that NRG1-IV overexpression results in concomitant changes in the ErbB4-PI3K signaling pathway.

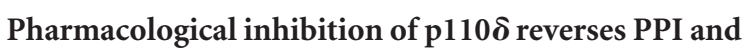
temporal order discrimination deficits in NRG1-IV/NSE-tTA mice

Recent data demonstrate that altered NRG1 signaling in schizophrenia involves increases in the expression of ErbB4 and the intracellular PIK3, PIK3CD and preclinical evidence suggests that drugs that inhibit $\mathrm{p} 110 \delta$ (i.e., IC87114) may represent a novel approach for treatment (Marder et al., 2011; Law et al., 2012). Given the increases in cortical ErbB4 and p $110 \delta$ protein in NRG1-IV/NSE-tTA mice, we hypothesized that pharmacological inhibition of $\mathrm{p} 110 \delta$ signaling would ameliorate schizophrenia-relevant behavioral phenotypes. When analyzing the effect of drug, we found a statistically significant interaction between genotype and drug treatment $\left(F_{(1,44)}=4.68 p=0.002\right)$ and a main effect of genotype $\left(F_{(1,44)}=2.87 p=0.027\right)$ on PPI. Specifically, IC87114 treatment rescued NRG1-IV-dependent PPI deficits, significantly improving PPI in drug-treated NRG1IV/NSE-tTA mice compared with vehicle-treated NRG1-IV/ NSE-tTA mice $\left(\mathrm{db} 74-\mathrm{db} 90 ; F_{(1,20)}=8.6-15.27, p<0.005\right.$; post hoc LSD; Fig. 7C). No impact of genotype or treatment $\times$ genotype interaction was observed on baseline startle $(p>0.05$; data not shown). Remarkably, administration of IC87114, before the test phase of the temporal order task, reversed discrimination deficits in NRG1-IV/NSE-tTA mice (Fig. 7D). A significant treat- 
ment $\times$ genotype interaction effect was observed $\left(F_{(1,36)}=5.6\right.$ $p=0.02)$, in which IC87114 treatment rescued temporal order discrimination deficits in NRG1-IV/NSE-tTA mice $(t=-2.27$, $\mathrm{df}_{13} ; p<0.05$; Fig. $7 D$ ). In contrast, no significant effect of IC87114 treatment in NRG1-IV/NSE-tTA mice was found in tests of sociability (Fig. $7 E-H$ ). These data demonstrate that selective behavioral phenotypes in NRG1-IV/NSE-tTA mice depend on hyperactivation of $\mathrm{p} 110 \delta$ and are amenable to pharmacological intervention with IC87714 in adulthood.

\section{Discussion}

The NRG1/ErbB signaling nexus represents a complex genetic network that plays multiple critical roles in neurodevelopment (Harrison and Law, 2006; Mei and Nave, 2014). The association of several members of the pathway with neurodevelopmental disorders, including schizophrenia (Blouin et al., 1998; Badner and Gershon, 2002; Stefansson et al., 2002; Stefansson et al., 2003; Corvin et al., 2004; Silberberg et al., 2006; Law et al., 2012; Agim et al., 2013; Network and Pathway Analysis Subgroup of Psychiatric Genomics, 2015), highlights them as targets for understanding pathogenic mechanisms and potential drug design. To assess the in vivo consequences of schizophrenia-associated NRG1-IV variation, we performed an in-depth characterization of the behavioral, electrophysiological, and biochemical phenotypes of a novel transgenic mouse engineered to overexpress the human NRG1-IV isoform. We find that NRG1-IV/NSE-tTA mice exhibit discrete deficits in sensorimotor gating, spatial learning, recency discrimination memory, and social interaction, with correlative electrophysiological phenotypes associated with abnormal cortical E/I balance and synaptic dysfunction. Our study also identifies a functional role and related signaling mechanism involving ErbB4 and PIK3CD for NRG1-IV in neural circuit formation and provides a novel and clinically relevant pharmacological rescue strategy.

Impairments in working memory and related cognitive functions critically dependent on engagement of the PFC and hippocampus are prominent neuropsychological features of schizophrenia (Callicott et al., 2003; Meyer-Lindenberg et al., 2005; Toulopoulou et al., 2010; Rasetti et al., 2011; Schaefer et al., 2013; Senkowski and Gallinat, 2015). NRG1-IV/NSE-tTA mice demonstrate impaired temporal order discrimination and object location memory but normal novel object preference. Information flow among the medial PFC, PRH cortex, and hippocampus is necessary for recency discrimination measured by the temporal order task (Barker et al., 2007, Barker and Warburton, 2011), but discrimination for novel-familiar objects and object location depends exclusively on the PRH cortex and hippocampus, respectively (Barker and Warburton, 2011). Our data suggest that NRG1-IV overexpression results in the impaired development and function of prefrontal cortical-hippocampal circuitry that is consistent with cognitive impairments observed in schizophrenia and those associated in human subjects with genetic variation at NRG1, rs6994992 (Hahn et al., 2006; Hall et al., 2006; Nicodemus et al., 2006; Knickmeyer et al., 2014). Interestingly, in agreement with findings in patients with schizophrenia (Holt et al., 2009; Maren et al., 2013), associative emotional acquisition of fear stimuli was normal in NRG1-IV/NSE-tTA mice. Together, these findings suggest impairments consistent with changes in specific domains of cognitive function relevant to schizophrenia.

NRG1/ErbB4 signaling is critical for the development of E/I balance in the brain, which is mediated directly via its effects on neurotransmission, synapse development, and plasticity (Fazzari et al., 2010; Wen et al., 2010; Ting et al., 2011; Del Pino et al., 2013; Agarwal et al., 2014). NRG1-IV/NSE-tTA mice exhibited a distinct and com- plex PFC-electrophysiological phenotype characterized by alterations in $\mathrm{mEPSC}$ and sEPSC frequency in layer $\mathrm{V}$ pyramidal neurons and alterations in the physiology of LTS and FS interneurons. Reductions in the frequency of mEPSCs in layer $\mathrm{V}$ pyramidal neurons were observed in the absence of changes in amplitude, suggesting that NRG1-IV overexpression leads to decreased synaptic numbers and/or suppression of vesicular glutamate release (Queenan et al., 2012). Consistently, neurons from NRG1-IV/NSE-tTA mice demonstrated dendritic spine pathology, consistent with reduced spine observations reported in postmortem brains of schizophrenia patients (Glantz and Lewis, 2000; Penzes et al., 2011) and with the electrophysiological phenotype. These findings demonstrate that NRG1-IV regulates glutamate transmission and PFC-pyramidal neuron development and activity, likely mediated via ErbB4expressing interneurons and GABAergic regulation of early excitatory synapse development (Barros et al., 2009; Fazzari et al., 2010; Wen et al., 2010; Del Pino et al., 2013; Yin et al., 2013).

Multiple lines of evidence suggest that GABAergic neurotransmission and cortical circuit function is disrupted in schizophrenia (Gonzalez-Burgos et al., 2011), but the genetic and cellular basis remains unclear. NRG1/ErbB4 signaling has been shown to be required for the formation of excitatory synapses onto GABAergic interneurons (Fazzari et al., 2010; Ting et al., 2011). ErbB4 localizes to axon terminals and postsynaptic densities of interneurons, including, $\mathrm{PV}^{+}$chandelier and basket cells; NRG1 regulates GABA release (Fazzari et al., 2010; Wen et al., 2010; Ting et al., 2011) and GABAergic interneuron EPSCs via its effects on ErbB4/PSD95 (Fazzari et al., 2010; Ting et al., 2011). Among the several proteins altered in NRG1-IV/NSE-tTA mice, ErbB4 and PSD95 were increased in the PFC in a direction similar to that seen in schizophrenia (Silberberg et al., 2006; Law et al., 2007; Law et al., 2012). Our findings of increased and maladaptive firing frequencies in LTS interneurons and increased amplitude of sEPSCs in FS, $\mathrm{PV}^{+}$neurons suggest that NRG1-IV, likely via increased interneuron ErbB4 levels, affects cortical GABA circuitry development and excitatory stimulation of GABAergic interneurons. These observations are potentially consistent with correlations between ErbB4 and in vivo GABA levels in humans (Marenco et al., 2011; Luykx et al., 2012) in which risk genetic variation in ErbB4, predictive of relatively higher ErbB4 expression, is associated with increased GABA levels (Marenco et al., 2011; Luykx et al., 2012) and recent findings in drug-naive patients with schizophrenia (de la Fuente-Sandoval et al., 2015). The absence of changes in the frequency or amplitude of mIPSCs in layer V pyramidal neurons is likely consistent with the observation that NRG1 induces only depolarization-evoked GABA release and does not affect basal GABA release (Woo et al., 2007). Future studies of sIPSCs are warranted in NRG1-IV/NSE-tTA mice. Although previous studies have identified a critical role for NRG/ErbB4 in the development of FS PV ${ }^{+}$interneurons (Fazzari et al., 2010; Wen et al., 2010; Mei and Nave, 2014), our findings implicate a novel role for NRG1-IV in LTS interneuron function. The role of LTS neurons in cortical circuits has been proposed to be very different from that of FS interneurons (Kawaguchi, 1997; Beierlein et al., 2000; Beierlein et al., 2003) in that their primary function may be as a back-up to provide inhibition when cortical activity reaches maximal levels (Beierlein et al., 2003; Hayut et al., 2011). The observation of increased firing rates and maladaptive firing patterns in PFC-LTS neurons of NRG1-IV/ NSE-tTA mice suggests that cortical circuit inhibition is severely altered in the context of NRG1-IV overexpression.

Less easy to reconcile are the observed increases in the frequency of sEPSCs in layer V PFC-pyramidal neurons that are indicative of spontaneous increased glutamatergic neuron activity in NRG1-IV/NSE-tTA mice. We speculate that this pat- 
tern may represent a homeostatic compensatory feedback mechanism to potentially overcome the synaptic deficits in glutamatergic transmission and the increased GABAergic interneuron activity. Such mechanisms have been proposed and studied intensely as compensatory forms for neural circuit adaptations (Pozo and Goda, 2010; Queenan et al., 2012).

The absence of impaired LTP of hippocampal synaptic transmission in NRG1-IV/NSE-tTA mice is somewhat surprising given that previous studies of NRG1, either in vitro (Kwon et al., 2005; Chen et al., 2010) or in vivo (Agarwal et al., 2014), suggest a role for NRG1 signaling in LTP. However, our findings are consistent with other NRG1 models of schizophrenia (Deakin et al., 2012) in which increased NRG1-I expression also failed to influence hippocampal LTP. The degree to which this corresponds to or is consistent with hippocampal deficits observed in the model and proposed hippocampal deficits in patients with schizophrenia requires further investigation.

Finally, NRG1-IV/NSE-tTA mice display increased expression of PIK3-p1108, consistent with that observed in patients with schizophrenia (Law et al., 2012). We hypothesized that pharmacological inhibition of $\mathrm{p} 110 \delta$ via acute administration of the specific inhibitor IC87114 would have therapeutic effects in NRG1-IV/NSE-tTA mice similar to those seen with equivalent dosing regimens in developmental lesion-induced and pharmacological-induced murine models of the disorder (Law et al., 2012). IC87114 reversed PPI and temporal order discrimination deficits in NRG1-IV/NSE-tTA mice. In this context, IC87114 exhibited procognitive therapeutic efficacy, highlighting a role for PIK3CD in learning and memory and targeting of $110 \delta$ as a novel treatment for cognitive dysfunction in schizophrenia. Studies are under way to assess potential dose-dependency effects of IC87114 and acute versus chronic administration, specifically as it relates to behaviors not affected by treatment with the current regimen; that is, deficits of social function. Furthermore, our studies are incorporating investigations of female NRG1-IV/NSEtTA mice to examine potential sex differences in genotype-phenotype outcomes and drug response.

Although previous studies have demonstrated that reversing NRG1 transgene expression diminishes behavioral deficits and synaptic dysfunction in mice (Yin et al., 2013; Luo et al., 2014), our data provide evidence that the effects of abnormal neurodevelopment, as manifest in behavior, can be reversed with an acute novel pharmacological approach. Given the immediate need for new antipsychotic drugs, we view this strategy to be more relevant to translational medicine. Nevertheless, our model is a conditional transgenic one in which transgene expression can be silenced. We are currently using the model to study critical windows of developmental vulnerability underlying the NRG1-IV transgene effects.

In summary, our data demonstrate that NRG1-IV overexpression in the murine brain produces behavioral and cognitive deficits that coexist with discrete alterations in PFC-E/I balance and synaptic plasticity similar to those seen in schizophrenia. Moreover, although the exact mechanisms contributing to these deficits remain to be understood fully, we demonstrate here that behavioral and cognitive deficits can be reversed by a novel pharmacological approach and provide further evidence of how genetic variation in NRG1 relating to NRG1-IV may be involved in the etiology of risk for schizophrenia.

\section{References}

Abi-Dargham A, Mawlawi O, Lombardo I, Gil R, Martinez D, Huang Y, Hwang DR, Keilp J, Kochan L, Van Heertum R, Gorman JM, Laruelle M (2002) Prefrontal dopamine D1 receptors and working memory in schizophrenia. J Neurosci 22:3708-3719. Medline
Agarwal A, Zhang M, Trembak-Duff I, Unterbarnscheidt T, Radyushkin K, Dibaj P, Martins de Souza D, Boretius S, Brzózka MM, Steffens H, Berning S, Teng Z, Gummert MN, Tantra M, Guest PC, Willig KI, Frahm J, Hell SW, Bahn S, Rossner MJ, et al. (2014) Dysregulated expression of neuregulin-1 by cortical pyramidal neurons disrupts synaptic plasticity. Cell Reports 8:1130-1145. CrossRef Medline

Agim ZS, Esendal M, Briollais L, Uyan O, Meschian M, Martinez LA, Ding Y, Basak AN, Ozcelik H (2013) Discovery, validation and characterization of Erbb4 and Nrg1 haplotypes using data from three genome-wide association studies of schizophrenia. PloS One 8:e53042. CrossRef Medline

Amodio DM, Frith CD (2006) Meeting of minds: the medial frontal cortex and social cognition. Nat Rev Neurosci 7:268-277. CrossRef Medline

Badner JA, Gershon ES (2002) Meta-analysis of whole-genome linkage scans of bipolar disorder and schizophrenia. Mol Psychiatry 7:405-411. CrossRef Medline

Barker GR, Warburton EC (2011) When is the hippocampus involved in recognition memory? J Neurosci 31:10721-10731. CrossRef Medline

Barker GR, Bird F, Alexander V, Warburton EC (2007) Recognition memory for objects, place, and temporal order: a disconnection analysis of the role of the medial prefrontal cortex and perirhinal cortex. J Neurosci 27:2948-2957. CrossRef Medline

Barros CS, Calabrese B, Chamero P, Roberts AJ, Korzus E, Lloyd K, Stowers L, Mayford M, Halpain S, Müller U (2009) Impaired maturation of dendritic spines without disorganization of cortical cell layers in mice lacking NRG1/ErbB signaling in the central nervous system. Proc Natl Acad Sci U S A 106:4507-4512. CrossRef Medline

Beierlein M, Gibson JR, Connors BW (2000) A network of electrically coupled interneurons drives synchronized inhibition in neocortex. Nat Neurosci 3:904-910. CrossRef Medline

Beierlein M, Gibson JR, Connors BW (2003) Two dynamically distinct inhibitory networks in layer 4 of the neocortex. J Neurophysiol 90: 2987-3000. CrossRef Medline

Blouin JL, Dombroski BA, Nath SK, Lasseter VK, Wolyniec PS, Nestadt G, Thornquist M, Ullrich G, McGrath J, Kasch L, Lamacz M, Thomas MG, Gehrig C, Radhakrishna U, Snyder SE, Balk KG, Neufeld K, Swartz KL, DeMarchi N, Papadimitriou GN, et al. (1998) Schizophrenia susceptibility loci on chromosomes $13 \mathrm{q} 32$ and $8 \mathrm{p} 21$. Nat Genet 20:70-73. CrossRef Medline

Braff DL, Geyer MA (1990) Sensorimotor gating and schizophrenia: human and animal model studies. Arch Gen Psychiatry 47:181-188. CrossRef Medline

Braff DL, Geyer MA, Light GA, Sprock J, Perry W, Cadenhead KS, Swerdlow NR (2001) Impact of prepulse characteristics on the detection of sensorimotor gating deficits in schizophrenia. Schizophr Res 49:171-178. CrossRef Medline

Callicott JH, Mattay VS, Verchinski BA, Marenco S, Egan MF, Weinberger DR (2003) Complexity of prefrontal cortical dysfunction in schizophrenia: more than up or down. Am J Psychiatry 160:2209-2215. CrossRef Medline

Chen J, Kelz MB, Zeng G, Sakai N, Steffen C, Shockett PE, Picciotto MR, Duman RS, Nestler EJ (1998) Transgenic animals with inducible, targeted gene expression in brain. Mol Pharmacol 54:495-503. Medline

Chen YJ, Zhang M, Yin DM, Wen L, Ting A, Wang P, Lu YS, Zhu XH, Li SJ, Wu CY, Wang XM, Lai C, Xiong WC, Mei L, Gao TM (2010) ErbB4 in parvalbumin-positive interneurons is critical for neuregulin 1 regulation of long-term potentiation. Proc Natl Acad Sci U S A 107:21818-21823. CrossRef Medline

Corvin AP, Morris DW, McGhee K, Schwaiger S, Scully P, Quinn J, Meagher D, Clair DS, Waddington JL, Gill M (2004) Confirmation and refinement of an 'at-risk' haplotype for schizophrenia suggests the EST cluster, Hs.97362, as a potential susceptibility gene at the Neuregulin-1 locus. Mol Psychiatry 9:208-213. CrossRef Medline

Deakin IH, Law AJ, Oliver PL, Schwab MH, Nave KA, Harrison PJ, Bannerman DM (2009) Behavioural characterization of neuregulin 1 type I overexpressing transgenic mice. Neuroreport 20:1523-1528. CrossRef Medline

Deakin IH, Nissen W, Law AJ, Lane T, Kanso R, Schwab MH, Nave KA, Lamsa KP, Paulsen O, Bannerman DM, Harrison PJ (2012) Transgenic overexpression of the type I isoform of neuregulin 1 affects working memory and hippocampal oscillations but not long-term potentiation. Cereb Cortex 22:1520-1529. CrossRef Medline

de la Fuente-Sandoval C, Reyes-Madrigal F, Mao X, León-Ortiz P, RodríguezMayoral O, Solís-Vivanco R, Favila R, Graff-Guerrero A, Shungu DC (2015) Cortico-striatal GABAergic and glutamatergic dysregulations in subjects at ultra-high risk for psychosis investigated with proton magnetic 
resonance spectroscopy. Int J Neuropsychopharmacol 19:pii:pyv105. CrossRef Medline

Del Pino I, García-Frigola C, Dehorter N, Brotons-Mas JR, Alvarez-Salvado E, Martínez de Lagrán M, Ciceri G, Gabaldón MV, Moratal D, Dierssen M, Canals S, Marín O, Rico B (2013) Erbb4 deletion from fast-spiking interneurons causes schizophrenia-like phenotypes. Neuron 79: 1152-1168. CrossRef Medline

Elvevåg B, Goldberg TE (2000) Cognitive impairment in schizophrenia is the core of the disorder. Crit Rev Neurobiol 14:1-21. Medline

Fazzari P, Paternain AV, Valiente M, Pla R, Luján R, Lloyd K, Lerma J, Marín O, Rico B (2010) Control of cortical GABA circuitry development by Nrg1 and ErbB4 signalling. Nature 464:1376-1380. CrossRef Medline

Glantz LA, Lewis DA (2000) Decreased dendritic spine density on prefrontal cortical pyramidal neurons in schizophrenia. Arch Gen Psychiatry 57:65-73. CrossRef Medline

Gonzalez-Burgos G, Fish KN, Lewis DA (2011) GABA neuron alterations, cortical circuit dysfunction and cognitive deficits in schizophrenia. Neural Plast 2011:723184. CrossRef Medline

Greenwood TA, Lazzeroni LC, Murray SS, Cadenhead KS, Calkins ME, Dobie DJ, Green MF, Gur RE, Gur RC, Hardiman G, Kelsoe JR, Leonard S, Light GA, Nuechterlein KH, Olincy A, Radant AD, Schork NJ, Seidman LJ, Siever LJ, Silverman JM, et al. (2011) Analysis of 94 candidate genes and 12 endophenotypes for schizophrenia from the Consortium on the Genetics of Schizophrenia. Am J Psychiatry 168:930-946. CrossRef Medline

Hahn CG, Wang HY, Cho DS, Talbot K, Gur RE, Berrettini WH, Bakshi K, Kamins J, Borgmann-Winter KE, Siegel SJ, Gallop RJ, Arnold SE (2006) Altered neuregulin 1-erbB4 signaling contributes to NMDA receptor hypofunction in schizophrenia. Nat Med 12:824-828. CrossRef Medline

Hall J, Whalley HC, Job DE, Baig BJ, McIntosh AM, Evans KL, Thomson PA, Porteous DJ, Cunningham-Owens DG, Johnstone EC, Lawrie SM (2006) A neuregulin 1 variant associated with abnormal cortical function and psychotic symptoms. Nat Neurosci 9:1477-1478. CrossRef Medline

Harrison PJ, Law AJ (2006) Neuregulin 1 and schizophrenia: genetics, gene expression, and neurobiology. Biol Psychiatry 60:132-140. CrossRef Medline

Hayut I, Fanselow EE, Connors BW, Golomb D (2011) LTS and FS inhibitory interneurons, short-term synaptic plasticity, and cortical circuit dynamics. PLoS Comput Biol 7:e1002248. CrossRef Medline

Holt DJ, Lebron-Milad K, Milad MR, Rauch SL, Pitman RK, Orr SP, Cassidy BS, Walsh JP, Goff DC (2009) Extinction memory is impaired in schizophrenia. Biol Psychiatry 65:455-463. CrossRef Medline

Howes OD, Murray RM (2014) Schizophrenia: an integrated sociodevelopmental-cognitive model. Lancet 383:1677-1687. CrossRef Medline

Ji Y, Yang F, Papaleo F, Wang HX, Gao WJ, Weinberger DR, Lu B (2009) Role of dysbindin in dopamine receptor trafficking and cortical GABA function. Proc Natl Acad Sci U S A 106:19593-19598. CrossRef Medline

Kato T, Abe Y, Sotoyama H, Kakita A, Kominami R, Hirokawa S, Ozaki M, Takahashi H, Nawa H (2011) Transient exposure of neonatal mice to neuregulin-1 results in hyperdopaminergic states in adulthood: implication in neurodevelopmental hypothesis for schizophrenia. Mol Psychiatry 16:307-320. CrossRef Medline

Kawaguchi Y (1995) Physiological subgroups of nonpyramidal cells with specific morphological characteristics in layer II/III of rat frontal cortex. J Neurosci 15:2638-2655. Medline

Kawaguchi Y (1997) Selective cholinergic modulation of cortical GABAergic cell subtypes. J Neurophysiol 78:1743-1747. Medline

Kéri S, Kiss I, Kelemen O (2009) Effects of a neuregulin 1 variant on conversion to schizophrenia and schizophreniform disorder in people at high risk for psychosis. Mol Psychiatry 14:118-119. CrossRef Medline

Knickmeyer RC, Wang J, Zhu H, Geng X, Woolson S, Hamer RM, Konneker T, Lin W, Styner M, Gilmore JH (2014) Common variants in psychiatric risk genes predict brain structure at birth. Cereb Cortex 24:1230-1246. CrossRef Medline

Knight ZA, Gonzalez B, Feldman ME, Zunder ER, Goldenberg DD, Williams O, Loewith R, Stokoe D, Balla A, Toth B, Balla T, Weiss WA, Williams RL, Shokat KM (2006) A pharmacological map of the PI3-K family defines a role for p110alpha in insulin signaling. Cell 125:733-747. CrossRef Medline

Kumari V, Das M, Zachariah E, Ettinger U, Sharma T (2005) Reduced prepulse inhibition in unaffected siblings of schizophrenia patients. Psychophysiology 42:588-594. CrossRef Medline

Kwon OB, Longart M, Vullhorst D, Hoffman DA, Buonanno A (2005)
Neuregulin-1 reverses long-term potentiation at CA1 hippocampal synapses. J Neurosci 25:9378-9383. CrossRef Medline

Law AJ (2014) Genetic mouse models of neuregulin 1: gene dosage effects, isoform-specific functions, and relevance to schizophrenia. Biol Psychiatry 76:89-90. CrossRef Medline

Law AJ, Lipska BK, Weickert CS, Hyde TM, Straub RE, Hashimoto R, Harrison PJ, Kleinman JE, Weinberger DR (2006) Neuregulin 1 transcripts are differentially expressed in schizophrenia and regulated by $5^{\prime}$ SNPs associated with the disease. Proc Natl Acad Sci U S A 103:6747-6752. CrossRef Medline

Law AJ, Kleinman JE, Weinberger DR, Weickert CS (2007) Diseaseassociated intronic variants in the ErbB4 gene are related to altered ErbB4 splice-variant expression in the brain in schizophrenia. Hum Mol Genet 16:129-141. Medline

Law AJ, Wang Y, Sei Y, O’Donnell P, Piantadosi P, Papaleo F, Straub RE, Huang W, Thomas CJ, Vakkalanka R, Besterman AD, Lipska BK, Hyde TM, Harrison PJ, Kleinman JE, Weinberger DR (2012) Neuregulin 1-ErbB4-PI3K signaling in schizophrenia and phosphoinositide 3-kinasep110delta inhibition as a potential therapeutic strategy. Proc Natl Acad Sci U S A 109:12165-12170. CrossRef Medline

Lee KH, Farrow TF, Spence SA, Woodruff PW (2004) Social cognition, brain networks and schizophrenia. Psychol Med 34:391-400. CrossRef Medline

Lesuisse C, Martin LJ (2002) Long-term culture of mouse cortical neurons as a model for neuronal development, aging, and death. J Neurobiol 51:9-23. CrossRef Medline

Lévesque M, Parent A (1998) Axonal arborization of corticostriatal and corticothalamic fibers arising from prelimbic cortex in the rat. Cereb Cortex 8:602-613. CrossRef Medline

Li B, Woo RS, Mei L, Malinow R (2007) The neuregulin-1 receptor erbB4 controls glutamatergic synapse maturation and plasticity. Neuron 54: 583-597. CrossRef Medline

Luo X, He W, Hu X, Yan R (2014) Reversible overexpression of bace1cleaved neuregulin-1 N-terminal fragment induces schizophrenia-like phenotypes in mice. Biol Psychiatry 76:120-127. CrossRef Medline

Luykx JJ, Vinkers CH, Bakker SC, Visser WF, van Boxmeer L, Strengman E, van Eijk KR, Lens JA, Borgdorff P, Keijzers P, Kappen TH, van Dongen EP, Bruins P, Verhoeven NM, de Koning TJ, Kahn RS, Ophoff RA (2012) A common variant in ERBB4 regulates GABA concentrations in human cerebrospinal fluid. Neuropsychopharmacology 37:2088-2092. CrossRef Medline

Maat A, van Montfort SJ, de Nijs J, Derks EM, Kahn RS, Linszen DH, van Os J, Wiersma D, Bruggeman R, Cahn W, de Haan L, Krabbendam L, MyinGermeys I; GROUP Investigators (2015) Emotion processing in schizophrenia is state and trait dependent. Schizophr Res 161:392-398. CrossRef Medline

Marder SR, Roth B, Sullivan PF, Scolnick EM, Nestler EJ, Geyer MA, Welnberger DR, Karayiorgou M, Guidotti A, Gingrich J, Akbarian S, Buchanan RW, Lieberman JA, Conn PJ, Haggarty SJ, Law AJ, Campbell B, Krystal JH, Moghaddam B, Sawa A, et al. (2011) Advancing drug discovery for schizophrenia. Ann NY Acad Sci 1236:30-43. CrossRef Medline

Maren S, Phan KL, Liberzon I (2013) The contextual brain: implications for fear conditioning, extinction and psychopathology. Nat Rev Neurosci 14:417-428. CrossRef Medline

Marenco S, Geramita M, van der Veen JW, Barnett AS, Kolachana B, Shen J, Weinberger DR, Law AJ (2011) Genetic association of ErbB4 and human cortical GABA levels in vivo. J Neurosci 31:11628-11632. CrossRef Medline

Mei L, Nave KA (2014) Neuregulin-ERBB signaling in the nervous system and neuropsychiatric diseases. Neuron 83:27-49. CrossRef Medline

Meyer-Lindenberg AS, Olsen RK, Kohn PD, Brown T, Egan MF, Weinberger DR, Berman KF (2005) Regionally specific disturbance of dorsolateral prefrontal-hippocampal functional connectivity in schizophrenia. Arch Gen Psychiatry 62:379-386. CrossRef Medline

Moon E, Rollins B, Mesén A, Sequeira A, Myers RM, Akil H, Watson SJ, Barchas J, Jones EG, Schatzberg A, Bunney WE, DeLisi LE, Byerley W, Vawter MP (2011) Lack of association to a NRG1 missense polymorphism in schizophrenia or bipolar disorder in a Costa Rican population. Schizophr Res 131:52-57. CrossRef Medline

Moore H, Geyer MA, Carter CS, Barch DM (2013) Harnessing cognitive neuroscience to develop new treatments for improving cognition in 
schizophrenia: CNTRICS selected cognitive paradigms for animal models. Neurosci Biobehav Rev 37:2087-2091. CrossRef Medline

Moy SS, Nadler JJ, Perez A, Barbaro RP, Johns JM, Magnuson TR, Piven J, Crawley JN (2004) Sociability and preference for social novelty in five inbred strains: an approach to assess autistic-like behavior in mice. Genes Brain Behav 3:287-302. CrossRef Medline

Nagai T, Ibata K, Park ES, Kubota M, Mikoshiba K, Miyawaki A (2002) A variant of yellow fluorescent protein with fast and efficient maturation for cell-biological applications. Nat Biotechnol 20:87-90. CrossRef Medline

Network and Pathway Analysis Subgroup of Psychiatric Genomics Consortium (2015) Psychiatric genome-wide association study analyses implicate neuronal, immune and histone pathways. Nat Neurosci 18:199-209. CrossRef Medline

Nicodemus KK, Luna A, Vakkalanka R, Goldberg T, Egan M, Straub RE, Weinberger DR (2006) Further evidence for association between ErbB4 and schizophrenia and influence on cognitive intermediate phenotypes in healthy controls. Mol Psychiatry 11:1062-1065. CrossRef Medline

Nicodemus KK, Law AJ, Luna A, Vakkalanka R, Straub RE, Kleinman JE, Weinberger DR (2009) A 5' promoter region SNP in NRG1 is associated with schizophrenia risk and type III isoform expression. Mol Psychiatry 14:741-743. CrossRef Medline

Ogren SO, Goldstein M (1994) Phencyclidine- and dizocilpine-induced hyperlocomotion are differentially mediated. Neuropsychopharmacology 11:167-177. CrossRef Medline

O'Neill MF, Shaw G (1999) Comparison of dopamine receptor antagonists on hyperlocomotion induced by cocaine, amphetamine, MK-801 and the dopamine D1 agonist C-APB in mice. Psychopharmacology (Berl) 145: 237-250. CrossRef Medline

Papaleo F, Crawley JN, Song J, Lipska BK, Pickel J, Weinberger DR, Chen J (2008) Genetic dissection of the role of catechol-O-methyltransferase in cognition and stress reactivity in mice. J Neurosci 28:8709-8723. CrossRef Medline

Papaleo F, Silverman JL, Aney J, Tian Q, Barkan CL, Chadman KK, Crawley JN (2011) Working memory deficits, increased anxiety-like traits, and seizure susceptibility in BDNF overexpressing mice. Learn Mem 18: 534-544. CrossRef Medline

Papaleo F, Yang F, Garcia S, Chen J, Lu B, Crawley JN, Weinberger DR (2012) Dysbindin-1 modulates prefrontal cortical activity and schizophrenia-like behaviors via dopamine/D2 pathways. Mol Psychiatry 17:85-98. CrossRef Medline

Paterson C, Law AJ (2014) Transient overexposure of neuregulin 3 during early postnatal development impacts selective behaviors in adulthood. PLoS One 9:e104172. CrossRef Medline

Paterson C, Wang Y, Kleinman JE, Law AJ (2014) Effects of schizophrenia risk variation in the NRG1 gene on NRG1-IV splicing during fetal and early postnatal human neocortical development. Am J Psychiatry 171: 979-989. CrossRef Medline

Penzes P, Cahill ME, Jones KA, VanLeeuwen JE, Woolfrey KM (2011) Dendritic spine pathology in neuropsychiatric disorders. Nat Neurosci 14: 285-293. CrossRef Medline

Powell SB, Weber M, Geyer MA (2012) Genetic models of sensorimotor gating: relevance to neuropsychiatric disorders. Curr Top Behav Neurosci 12:251-318. CrossRef Medline

Pozo K, Goda Y (2010) Unraveling mechanisms of homeostatic synaptic plasticity. Neuron 66:337-351. CrossRef Medline

Queenan BN, Lee KJ, Pak DT (2012) Wherefore art thou, homeo(stasis)? Functional diversity in homeostatic synaptic plasticity. Neural Plast 2012: 718203. CrossRef Medline

Rapoport JL, Giedd JN, Gogtay N (2012) Neurodevelopmental model of schizophrenia: update 2012. Mol Psychiatry 17:1228-1238. CrossRef Medline

Rasetti R, Sambataro F, Chen Q, Callicott JH, Mattay VS, Weinberger DR (2011) Altered cortical network dynamics: a potential intermediate phenotype for schizophrenia and association with ZNF804A. Arch Gen Psychiatry 68:1207-1217. CrossRef Medline

Schaefer J, Giangrande E, Weinberger DR, Dickinson D (2013) The global cognitive impairment in schizophrenia: consistent over decades and around the world. Schizophr Res 150:42-50. CrossRef Medline

Schizophrenia Working Group of the Psychiatric Genomics Consortium (2014) Biological insights from 108 schizophrenia-associated genetic loci. Nature 511:421-427. CrossRef Medline

Senkowski D, Gallinat J (2015) Dysfunctional prefrontal gamma-band os- cillations reflect working memory and other cognitive deficits in schizophrenia. Biol Psychiatry 77:1010-1019. CrossRef Medline

Silberberg G, Darvasi A, Pinkas-Kramarski R, Navon R (2006) The involvement of ErbB4 with schizophrenia: association and expression studies. Am J Med Genet 141B:142-148. CrossRef Medline

Stefanis NC, Trikalinos TA, Avramopoulos D, Smyrnis N, Evdokimidis I, Ntzani EE, Ioannidis JP, Stefanis CN (2007) Impact of schizophrenia candidate genes on schizotypy and cognitive endophenotypes at the population level. Biol Psychiatry 62:784-792. CrossRef Medline

Stefansson H, Sigurdsson E, Steinthorsdottir V, Bjornsdottir S, Sigmundsson T, Ghosh S, Brynjolfsson J, Gunnarsdottir S, Ivarsson O, Chou TT, Hjaltason O, Birgisdottir B, Jonsson H, Gudnadottir VG, Gudmundsdottir E, Bjornsson A, Ingvarsson B, Ingason A, Sigfusson S, Hardardottir H, et al. (2002) Neuregulin 1 and susceptibility to schizophrenia. Am J Hum Genet 71:877-892. CrossRef Medline

Stefansson H, Sarginson J, Kong A, Yates P, Steinthorsdottir V, Gudfinnsson E, Gunnarsdottir S, Walker N, Petursson H, Crombie C, Ingason A, Gulcher JR, Stefansson K, St Clair D (2003) Association of neuregulin 1 with schizophrenia confirmed in a Scottish population. Am J Hum Genet 72:83-87. CrossRef Medline

Tan W, Wang Y, Gold B, Chen J, Dean M, Harrison PJ, Weinberger DR, Law AJ (2007) Molecular cloning of a brain-specific, developmentally regulated neuregulin 1 (NRG1) isoform and identification of a functional promoter variant associated with schizophrenia. J Biol Chem 282:2434324351. CrossRef Medline

Tang TT, Yang F, Chen BS, Lu Y, Ji Y, Roche KW, Lu B (2009) Dysbindin regulates hippocampal LTP by controlling NMDA receptor surface expression. Proc Natl Acad Sci U S A 106:21395-21400. CrossRef Medline

Ting AK, Chen Y, Wen L, Yin DM, Shen C, Tao Y, Liu X, Xiong WC, Mei L (2011) Neuregulin 1 promotes excitatory synapse development and function in GABAergic interneurons. J Neurosci 31:15-25. CrossRef Medline

Toulopoulou T, Goldberg TE, Mesa IR, Picchioni M, Rijsdijk F, Stahl D, Cherny SS, Sham P, Faraone SV, Tsuang M, Weinberger DR, Seidman LJ, Murray RM (2010) Impaired intellect and memory: a missing link between genetic risk and schizophrenia? Arch Gen Psychiatry 67:905-913. CrossRef Medline

Weickert CS, Tiwari Y, Schofield PR, Mowry BJ, Fullerton JM (2012) Schizophrenia-associated HapICE haplotype is associated with increased NRG1 type III expression and high nucleotide diversity. Transl Psychiatry 2:e104. CrossRef Medline

Weickert TW, Goldberg TE, Gold JM, Bigelow LB, Egan MF, Weinberger DR (2000) Cognitive impairments in patients with schizophrenia displaying preserved and compromised intellect. Arch Gen Psychiatry 57:907-913. CrossRef Medline

Weinberger DR (1987) Implications of normal brain development for the pathogenesis of schizophrenia. Arch Gen Psychiatry 44:660-669. CrossRef Medline

Wen L, Lu YS, Zhu XH, Li XM, Woo RS, Chen YJ, Yin DM, Lai C, Terry AV Jr, Vazdarjanova A, Xiong WC, Mei L (2010) Neuregulin 1 regulates pyramidal neuron activity via ErbB4 in parvalbumin-positive interneurons. Proc Natl Acad Sci U S A 107:1211-1216. CrossRef Medline

Winterer G, Weinberger DR (2004) Genes, dopamine and cortical signalto-noise ratio in schizophrenia. Trends Neurosci 27:683-690. CrossRef Medline

Woo RS, Li XM, Tao Y, Carpenter-Hyland E, Huang YZ, Weber J, Neiswender H, Dong XP, Wu J, Gassmann M, Lai C, Xiong WC, Gao TM, Mei L (2007) Neuregulin-1 enhances depolarization-induced GABA release. Neuron 54:599-610. CrossRef Medline

Xiang Z, Huguenard JR, Prince DA (1998) GABAA receptor-mediated currents in interneurons and pyramidal cells of rat visual cortex. J Physiol 506:715-730. CrossRef Medline

Yang CR, Seamans JK (1996) Dopamine D1 receptor actions in layers V-VI rat prefrontal cortex neurons in vitro: modulation of dendritic-somatic signal integration. J Neurosci 16:1922-1935. Medline

Yin DM, Chen YJ, Lu YS, Bean JC, Sathyamurthy A, Shen C, Liu X, Lin TW, Smith CA, Xiong WC, Mei L (2013) Reversal of behavioral deficits and synaptic dysfunction in mice overexpressing neuregulin 1. Neuron 78: 644-657. CrossRef Medline

Young JW, Geyer MA (2015) Developing treatments for cognitive deficits in schizophrenia: the challenge of translation. J Psychopharmacol 29: 178-196. CrossRef Medline 